\title{
Erosion and accretion in the Ria de Aveiro inlet ( $N$ Portugal) and exportation of fine-grained sediments to the shelf
}

\author{
Erosión y acumulación en la entrada de la Ría de Aveiro (N Portugal) y \\ la exportación de sedimentos de grano fino a la plataforma
}

\author{
V. Martins ${ }^{1,2, *}$, C. Grangeia ${ }^{1}$, C. C. Jesus ${ }^{1}$, P. Martins ${ }^{3}$, L. M. Laut ${ }^{4}$, C. Sequeira ${ }^{1}$, J.M. Dias ${ }^{4}$, \\ P. A. Silva ${ }^{4}$, I. Abrantes ${ }^{5}$, E. Ferreira da Silva ${ }^{1}$, F. Rocha ${ }^{1}$ \\ ${ }^{1}$ GeoBioTec Research Centre, University of Aveiro, Dpt. of Geosciences, Campus de Santiago, 3810-193 Aveiro, Portugal \\ (virginia.martins@ua.pt; cgrangeia@ua.pt; carlos.jesus@ua.pt; csequeira@ua.pt; eafsilva@ua.pt; tavares.rocha@ua.pt) \\ ${ }^{2}$ CESAM, University of Aveiro, Department of Geosciences, CESAM, Aveiro, Portugal \\ ${ }^{4}$ Institute of Biosciences, University of the State of Rio de Janeiro - Unirio, Brazil \\ (lazarolaut@hotmail.com) \\ ${ }^{5}$ CESAM, University of Aveiro Department of Physics, Aveiro, Portugal \\ (joao.dias@ua.pt; psilva@ua.pt) \\ ${ }^{6}$ ESEV Polytechnic Institute of Viseu 3504-504 Viseu, Portugal \\ (iabrantes@esev.ipv.pt) \\ *corresponding author
}

Received: 05/04/11 / Accepted: 19/10/11

\begin{abstract}
Harbours are important man made economic structures that are usually constructed in hydrodynamic complex settings. Their life/ service cycle, integrity and maintenance are highly dependent on the knowledge of these settings and the capability to predict future changes and thus their economic impact. In this paper, data regarding bottom and suspended sediments of the Aveiro Harbour inlet were gathered and analysed.

Measurements of suspended sediment concentrations (SSC) in the Aveiro inlet were taken during eight tidal cycles in 2007, including spring and neap tides throughout winter and summer oceanographic regimes. Results suggest significant temporal variability.

Sediments were imported from the ocean sink, mostly near the south jetty and the western side of the Mira Channel, as textural, mineralogical, compositional, geochemical and microfaunal data of bottom sediments suggest. Higher stabilization of the Aveiro Harbour structures is achieved on these accretional areas.

The high tidal-current velocities contribute to the erosive character which dominates the central area of the entrance channel, which is located between both breakwaters and close to the north jetty; thus some segments of the north jetty could become damaged through erosion. This is evidenced as much bottom sediments characteristics as patterns of SSC.

SSC are in general higher during the winter, due to climatic conditions, current velocities, wind stress and greater availability of sediments provided by the local-river flooding. Our data also suggest that SSC are predominantly higher during ebb and low tide
\end{abstract}


throughout the year, as compared to periods of flood, when a higher flux of sediments is transported seaward than landward. The lagoon exports to the continental shelf mostly muddy sediments, composed essentially of quartz and phyllosilicates.

Keywords: multiproxy approach, tidal currents, suspended and bottom sediments, Ria de Aveiro, N Portugal

\section{Resumen}

Los puertos son importantes estructuras económicas diseñadas por el hombre, que normalmente son construidas en lugares con una compleja hidrodinámica. Su ciclo de vida de servicio, integridad y mantenimiento dependen del conocimiento de dicha hidrodinámica y de la capacidad para predecir los cambios futuros y por tanto su impacto económico. En este trabajo, los datos sobre los sedimentos que están en el fondo y en suspensión de la entrada del puerto de Aveiro fueron recogidos y analizados.

Las mediciones de la concentración de sedimentos en suspensión (SSC) en la entrada de Aveiro se realizaron durante ocho ciclos de las mareas en el año 2007, incluyendo mareas vivas y muertas durante regímenes oceanográficos de invierno y verano. Los resultados sugieren que la variabilidad temporal es significativa.

Los sedimentos importados desde el océano se hunden en su mayoría cerca de la escollera sur y en el lado occidental del Canal de Mira, tal y como sugieren los datos texturales, mineralógicos, composicionales, geoquímicos y microfaunales de los sedimentos del fondo. La mayor estabilización de las estructuras del puerto de Aveiro se logra en estas áreas de acreción.

La alta velocidad de la corriente de marea contribuye al carácter erosivo, que domina la zona central del canal de entrada, entre los dos espigones y cerca de la escollera norte. Así, algunos segmentos del muelle N podrían resultar dañados por el efecto de la erosión. Esto se pone de manifiesto tanto en las características de los sedimentos del fondo como de los patrones de SSC.

Las SSC son en general más altas durante el invierno, debido a las condiciones climáticas, velocidades de la corriente, y a la fuerza del viento y a una mayor disponibilidad de sedimentos aportados por los ríos locales. Nuestros datos también sugieren concentraciones mayores de SSC durante la marea baja (durante todo el año), que durante la marea alta, mostrando que existe un mayor flujo de sedimentos transportado hacia el mar que hacia tierra. La laguna exporta a la plataforma continental sobre todo sedimentos fangosos, compuestos esencialmente por cuarzo y filosilicatos.

Palabras clave: enfoque multiproxy, corrientes de marea, sedimentos en suspensión y en el fondo, Ría de Aveiro, N de Portugal

\section{Introduction}

The Ria de Aveiro is the most extensive coastal lagoon of the Western coast of Portugal, roughly located between Espinho city and Cabo Mondego (40³8'N, $8^{\circ} 44^{\prime} \mathrm{W}$ ), enclosed by a large sand barrier (Fig. 1).

The lagoon formation has evolved since the $10^{\text {th }}$ century, when a sandy spit started to proceed southwards from Espinho until the mouth of the Vouga River, isolating progressively the ancient bay from the sea (Abecasis, 1955). This sand spit grew southwards whereas another sand spit developed from Cabo Mondego northwards. The sand spits temporarily closed the communication between the lagoon and the sea in 1575. Since then, the natural inlet has migrated although it has recurrently suffered from obstructions, as was described by Abecasis (1955). From the middle of the $18^{\text {th }}$ century, blockages in the flow between the lagoon and the sea became more frequent, with disastrous consequences not only for maritime activities but also for the public health of the local population (Amorim, 2008; Amaral, 1968).

Consequently an artificial inlet was opened in 1808 , which has since remained as the primary opening, servicing the Aveiro Harbour and its activities (fishing, industrial, commercial and recreational activities). The jetties that help maintain the lagoon mouth open have been the subject of several maintenance projects since being built. An extensive list of these interventions can be found in Plecha et al. (2010). Presently, the channel of the inlet is $1.3 \mathrm{~km}$ long, $350 \mathrm{~m}$ wide and $25 / 30 \mathrm{~m}$ deep and connects the lagoonal body to the Atlantic Ocean (Fig. 1).

At present, the lagoon is $45 \mathrm{~km}$ long and $10 \mathrm{~km}$ wide, covering an area corresponding approximately to a minimum of $66 \mathrm{~km}^{2}$, at low spring tides, and a maximum of $83 \mathrm{~km}^{2}$, at high spring tides (Dias and Lopes, 2006). The main portion of the Aveiro lagoon is comprised of a complex dendritic pattern of channels, characterised by the existence of significant intertidal zones, namely mud flats and salt marshes, with four main branches connected to the entrance: Mira, S. Jacinto, Ílhavo and Espinheiro Channels (Dias et al., 2001). The Mira and S. Jacinto Channels are in the continuity of the Ria de Aveiro inlet. In the inner parts of the lagoon there is an extensive tributary area supplying this system with fresh water and sediments, but the only two important rivers flowing to the lagoon are: the Vouga River and the Antuã River with an annual mean discharge of $50 \mathrm{~m}^{3} \mathrm{~s}^{-1}$ and $5 \mathrm{~m}^{3} \mathrm{~s}^{-1}$, respectively (Moreira et al., 1993).

Water circulation in the lagoon is influenced by the wind and river runoff but is almost totally dependent on tidal energy (Dias et al., 2000; Vaz and Dias, 2008). 

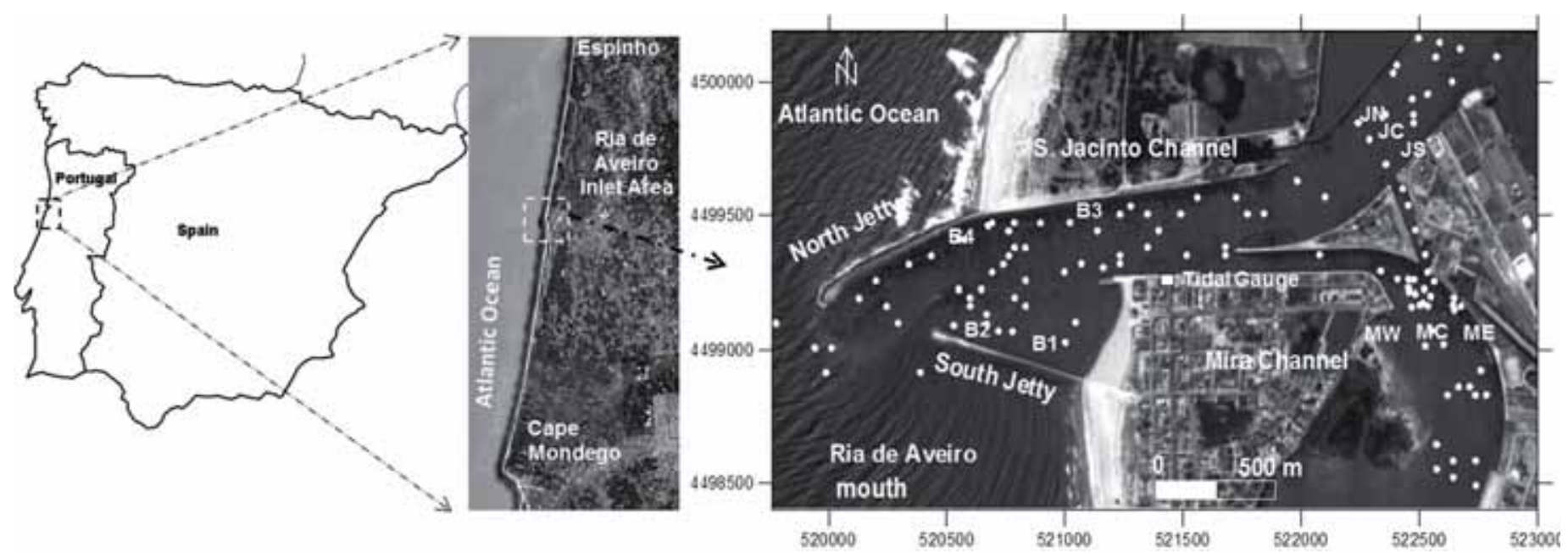

Fig. 1. - Study area and grab-samples location. The positions of the stations for SPM collection are found in: Aveiro inlet, B1-B4; S. Jacinto Channel, JN, JC, JS; Mira Channel, MW, MC, ME.

Fig. 1. - Área de estudio y ubicación de las muestras recogidas. La ubicación de las estaciones para la recogida de SPM se encuentra en: la entrada de la Ría de Aveiro, B1-B4, Canal de S. Jacinto, JN, JC, JS; Canal de Mira, MW, MC, ME.

Tides are semidiurnal and tidal range varies between $0.6 \mathrm{~m}$ (neap tides) and $3.2 \mathrm{~m}$ (spring tides), with an average range at the inlet of about $2 \mathrm{~m}$ (Dias et al., 2000; Sousa and Dias, 2007). The tides are higher on ebb than on flood (Dias et al., 2000), revealing an ebb dominated system (Picado et al., 2010). The ebb jet extends into the shelf as shown by numerical simulations of the ocean circulation in the vicinity of the inlet (Silva et al., 2009).

Understanding the erosion and accretion trends in the Ria de Aveiro inlet and surrounding areas is an important issue in order to predict the evolution of the lagoon, considering that the inlet channel depth determines the tidal prism, tidal velocities and sea surface elevation along the lagoon (Araújo et al., 2008; Picado et al, 2010). Regarding the adjacent coastal evolution, which has shown a significant retreat, according to Dias et al. (1994) and Oliveira et al. (1982), it's important to evaluate the lagoon sediment exchange with the littoral drift.

The sediment transport in the lagoon is essentially determined by the tidal currents' intensity and phase (Lopes et al., 2006) and by the marine and fluvial sediment supply (Abrantes et al., 2006), whereas the sediments balance in the inlet and adjacent areas is also determined by the wave regime (Plecha et al., 2010).

This paper presents results obtained under the framework of the EMERA project (Morfodynamic Study of Ria de Aveiro Inlet) aiming: i) to perform a sediment characterization of the Ria de Aveiro inlet; ii) to identify the erosion/ deposition trends in the tidal inlet and surrounding area; iii) to identify areas where marine sediment contributions are important; iv) to analyse the process of sediment supply to the continental shelf.

\section{Materials and Methods}

\subsection{Bottom sediments}

The study area is located in the Ria de Aveiro (N Portugal) inlet and surrounding areas, i.e. the S. Jacinto and Mira channels (Fig. 1). A set of 113 surface sediment grab (Petit Ponar) samples were collected at the study area during different oceanographic campaigns throughout 2006 and 2007. At each sampling station the water depth was evaluated using the boat sonar. The metric coordinates and depth of the studied sites, as well as the dates on which samples were collected, have been included in Appendix 1.

In each station, two sub-samples of surface sediment (first $\approx 5 \mathrm{~cm}$ ) were collected. One batch of sub-samples was preserved for textural, mineralogical and geochemical analyses. The other batch of sub-samples, at least $500 \mathrm{ml}$ of sediment, was preserved by adding a rose Bengal solution in $90 \%$ ethanol with the aim of studying foraminifera assemblages. Rose Bengal was used in order to discriminate between live (red-stained protoplasm) and dead foraminifers (empty tests).

Grain size analysis was performed by the classic sieving method. Sediment grain sizes were evaluated by the Folk and Ward method, using the scale in microns. Mineralogical and geochemical studies were carried out on a grounded split of the sediment fraction $<2000 \mu \mathrm{m}$ of each sample. The samples were ground until they reached sedimentary particles smaller than $63 \mu \mathrm{m}$. Geochemical and mineralogical analyses were performed on the milled sediments. 
The mineralogical studies were carried out using X-ray diffraction (XRD) techniques, according to the procedures described by Martins et al. (2007). Concentrations of $\mathrm{Al}, \mathrm{Ba}, \mathrm{Ca}, \mathrm{Ce}, \mathrm{Cr}, \mathrm{K}, \mathrm{La}, \mathrm{Li}, \mathrm{Mg}, \mathrm{Mn}, \mathrm{Na}, \mathrm{P}, \mathrm{Rb}, \mathrm{S}$, $\mathrm{Sr}$, Th, Ti, V, Zn and Zr were determined by ICP-MS (Inductively Coupled Plasma-Mass Spectrometer) analysis after a 4-acid digestion $\left(\mathrm{HClO}_{4}-\mathrm{HNO}_{3}-\mathrm{HCl}-\mathrm{HF}\right)$, at an international accredited laboratory - ACME Analytical Laboratories Ltd - ISO 9002 Accredited Co.

Each sample for foraminifera analysis was carefully washed with fresh water using $63-\mu \mathrm{m}$ and $1000-\mu \mathrm{m}$ mesh sieves, to remove mud-size sediments and the excess of rose Bengal solution, and dried in an oven, at $40-50^{\circ} \mathrm{C}$, until the sample was thoroughly dry. Benthic foraminifera studies were performed using a light binocular microscope. Dead and living foraminifera densities, i.e. the number of tests/ individuals per gram of the sediment fraction $63-500 \mu \mathrm{m}$, were determined in each sample. This sediment fraction was chosen because it includes the greater part of the specimens of the group studied in the Ria de Aveiro. Also, this method avoids significantly reduced foraminifera density values caused by coarser and denser terrigenous grains.

The study of the dead and living assemblages of benthic foraminifera was made on the dried residue $(63-1000 \mu \mathrm{m})$ of each sample. The generic assignments followed Loeblich and Tappan (1987). Species identification was based on references cited by Martins and Gomes (2004), as well as on the Ellis and Messina Catalogue (1940 and subsequent). In order to characterize the composition of the assemblage by percentage of each species, about 300 empty and 300 pink coloured (living specimens) foraminifera tests was considered an ideal number. In samples where the number of specimens was lower than 100 , the percentage of individuals per species and per sample in the dead and/ or in the living assemblages was not determined. The Shannon index (Shannon, 1948; H $=-\Sigma$ pi. $\ln (\mathrm{pi})$, where pi is the proportion of each species) was used to identify the dead assemblage diversity. The use of this index has advantages because it incorporates the species richness and evenness and is applicable to a simple statistical analysis.

The proportion of imported shells from the ocean was determined, taking into account several aspects: the degree of degradation due to transport of foraminifera tests (the number of tests degraded by transport was recorded and duly noted in the initial data table) and the study of the patterns of distribution of living foraminifera in the Ria de Aveiro (according to the work of Martins et al., included in this volume), which permitted the identification of faunas more characteristic of oceanic or lagoonal environments. Previous studies analyzing foraminifera distribu- tion in other Iberian coastal and lagoonal areas were also taken in account (e.g. Alejo et al., 1999; Cearreta, 1988 a, b, 1989; Cearreta et al., 2000, 2002; Diz et al., 2004, 2006; González-Regalado et al., 1996; Moreno et al., 2005; Muñoz et al., 1996; Pascual, 1984, 1992) and elsewhere (Murray, 1991). The proportion of empty tests imported from the ocean is hereafter referred to in this work as 'oceanic specimens'. The species list considered in this analysis is detailed in the following section (Results).

Areas affected by erosion or accretion have been identified by using bottom sediments' textural, mineralogical, geochemical and microfaunal data (foraminifera density and percentage of 'oceanic specimens'). A higher density of empty foraminifera tests indicates areas where sediments are being essentially deposited. The variation of the percentage of 'oceanic specimens' was used as a proxy to trace how important is the contribution of sedimentary particles originated in oceanic areas in the lagoon. The mineralogical and geochemical composition of the surface sediments was also used to help indicate areas with higher marine influence in the Ria de Aveiro inlet and surrounding areas.

Discrimination of spatial variations between dead and living assemblages, in all samples, was compared through a presence/ absence matrix by applying the Bray Curtis coefficient and using the program Primer 06. In order to discriminate the relationships of textural, mineralogical, geochemical and microfaunal data within samples and between the sampled stations, cluster analysis was applied, using Statistica V.07 software.

\subsection{Suspended sediments}

Temporal variation of suspended sediment concentrations (SSC) was addressed by collecting samples of water on eight occasions during 2007, including winter and summer oceanographic regimes (Table 1). Sampling was performed at approximately 3-hour intervals, during 4 neap and spring tidal cycles, at ten stations located near the lagoon mouth (Fig. 1): lagoon inlet - stations B1, B2, B3 and B4; S. Jacinto Channel-JN, JC, and JS and; Mira Channel - ME, MC, MO. Water samples were collected from the surface, middle-depth and $1 \mathrm{~m}$ above the bottom at each site, with a horizontal Van Dorn ${ }^{\circledR}$ bottle (4.51 capacity).

Suspended sediment concentrations were determined according to the methodology applied by Abrantes et al. (2006). Between 1 and 3 litre aliquots were filtered with the classic vacuum system using $0.45 \mu \mathrm{m}$ Millipore ${ }^{\circledR}$ ( $47 \mathrm{~mm}$ diameter) pre-weighted filters. The filters were dried at $40^{\circ} \mathrm{C}$ for $24 \mathrm{~h}$ and reweighed. In some selected suspended sediment samples, sediments' grain size and 


\begin{tabular}{|c|c|c|c|c|}
\hline & \multicolumn{2}{|c|}{$\begin{array}{c}\text { Spring Tide } \\
\text { (dates, tidal phase and time of sampling water) }\end{array}$} & \multicolumn{2}{|c|}{$\begin{array}{c}\text { Neap Tide } \\
\text { (dates, tidal phase and time of sampling water) }\end{array}$} \\
\hline \multirow{5}{*}{ 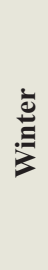 } & 03.04.2007 & 04.04.2007 & 28.03.2007 & 29.03.2007 \\
\hline & LT-3 - 7.19h & LT-3 - 7.46h & HT-3 - 9.13h & $\mathrm{LT}-6.45 \mathrm{~h}$ \\
\hline & LT $-10.19 \mathrm{~h}$ & LT $-10.46 \mathrm{~h}$ & $\mathrm{HT}-12.13 \mathrm{~h}$ & HT-3 - 10.05h \\
\hline & HT-3 - $13.45 \mathrm{~h}$ & HT-3 - 14.13h & LT-3 - 15.04h & HT $-13.05 \mathrm{~h}$ \\
\hline & HT $-16.45 \mathrm{~h}$ & HT $-17.13 \mathrm{~h}$ & LT - 18.04h & LT-3 - 16.05h \\
\hline \multirow{5}{*}{$\begin{array}{l}\dot{\bar{\Xi}} \\
\bar{\Xi} \\
\bar{\Xi}\end{array}$} & 03.07.2007 & 05.07.2007 & 9.07.2007 & 11.07.2007 \\
\hline & LT-3 - 8.15h & $\mathrm{HT}-7.18 \mathrm{~h}$ & HT-3 $-8.12 \mathrm{~h}$ & $\mathrm{LT}-6.49 \mathrm{~h}$ \\
\hline & $\mathrm{LT}-11.31 \mathrm{~h}$ & $\mathrm{HT}+3-10.18 \mathrm{~h}$ & $\mathrm{HT}-11.12 \mathrm{~h}$ & HT-3 - 10.26h \\
\hline & HT-3 - $14.45 \mathrm{~h}$ & $\mathrm{LT}-13.00 \mathrm{~h}$ & LT-3 - 14.12h & HT $-13.26 \mathrm{~h}$ \\
\hline & HT $-18.09 \mathrm{~h}$ & $\mathrm{LT}+3-16.00 \mathrm{~h}$ & $\mathrm{LT}-17.08 \mathrm{~h}$ & LT-3 - 16.26h \\
\hline
\end{tabular}

Table 1.- Dates of sampling campaign in 2007, including winter and summer oceanographic regimes, during 4 neap and spring tidal cycles. The timetable of the water sample collection is also presented (low tide - LT; high tide - HT).

Tabla 1.- Las fechas de la campaña de muestreo en el año 2007, incluyendo los regímenes oceanográficos de invierno y verano, durante 4 ciclos de mareas vivas y muertas. También se presenta el horario de recogida de muestras de agua (marea baja - LT; marea alta $-\mathrm{HT}$ ).

mineralogy was analysed by laser diffraction (Mastersizer S instrument, Malvern Instruments) and X-ray diffraction techniques (XRD), respectively.

\section{Results}

\subsection{Bottom Sediments}

Sediment median grain sizes (D50) were found to vary between $0.041 \mathrm{~mm}$ and $3.7 \mathrm{~mm}$. Most of the surface sediment of the studied area is composed of sand. The coarse sediment fraction, $>250 \mu \mathrm{m}$, varies from almost $2.5 \%$ to $99 \%$, in individual samples. 'Poorly sorted' coarse sand and gravel are found mostly along the S. Jacinto Channel, in the central area of the Ria de Aveiro inlet and close to the north jetty. In more sheltered areas, such as at the western side of the Mira Channel, near the south jetty and at the head of north jetty, 'moderately well sorted' and 'well sorted' fine sand and coarse silt predominate.

Sediments in the area are composed mainly of quartz (95-25\%), phyllosilicates $(<52 \%)$, plagioclase $(45-1 \%)$, $\mathrm{K}$-feldspars $(40-2 \%)$, calcite $(<16 \%)$ and dolomite $(<7 \%)$. Other minerals such as opal $\mathrm{C} / \mathrm{T}$, anhydrite, siderite, anatase, zeolites, alunite, magnetite, hematite and pyrite are vestigial.

Concentrations of $\mathrm{Al}, \mathrm{Ba}, \mathrm{Ca}, \mathrm{Ce}, \mathrm{Cr}, \mathrm{K}, \mathrm{La}, \mathrm{Li}, \mathrm{Mg}$, $\mathrm{Mn}, \mathrm{Na}, \mathrm{P}, \mathrm{Rb}, \mathrm{S}, \mathrm{Sr}$, Th, Ti, $\mathrm{V}, \mathrm{Zn}$ and $\mathrm{Zr}$ are included in Appendix 1. The distribution patterns of these chemical elements are subsequently detailed in the statistical analyses section.
Appendix 1 also contains the stations' coordinates, as well as other sedimentological data (grain size, and mineralogical composition) and selected microfaunal results (Shannon index values, foraminifera density, percentage of the most abundant dead and living benthic foraminifera species and groups of those species, as well as the percentage of 'oceanic specimens'). Maximum, minimum and median values of those variables are also listed.

The density of dead foraminifera is less than around 2300 tests per gram of sediment. However the abundance of foraminifera is in general very low in many of the studied stations. The percentage of dead and living species was not determined in $20 \%$ and $38 \%$ of the samples, respectively, due to the reduced number of specimens.

Dead benthic foraminifera assemblages were composed of around 175 species and, among these, around 112 species were found to be alive. The number and the percentage of individuals per species, in each sample, in dead and living benthic foraminifera assemblages are presented in Appendix 2.

The results from discrimination analysis of the spatial variations between dead and living assemblages (considering the samples with dead and living specimens), applying the Bray Curtis coefficient to a presence/absence matrix, are reported in Fig. 2. This analysis separates the dead from the living assemblage of most of the samples.

The dead assemblage of the studied area is mostly composed of Ammonia tepida ( $<65 \%$ ), Planorbulina mediterranensis $(<42 \%)$, Cibicides ungerianus $(<38 \%)$, Lobatula lobatula $(<26 \%)$, Gavelinopsis praegeri $(<22 \%)$, 


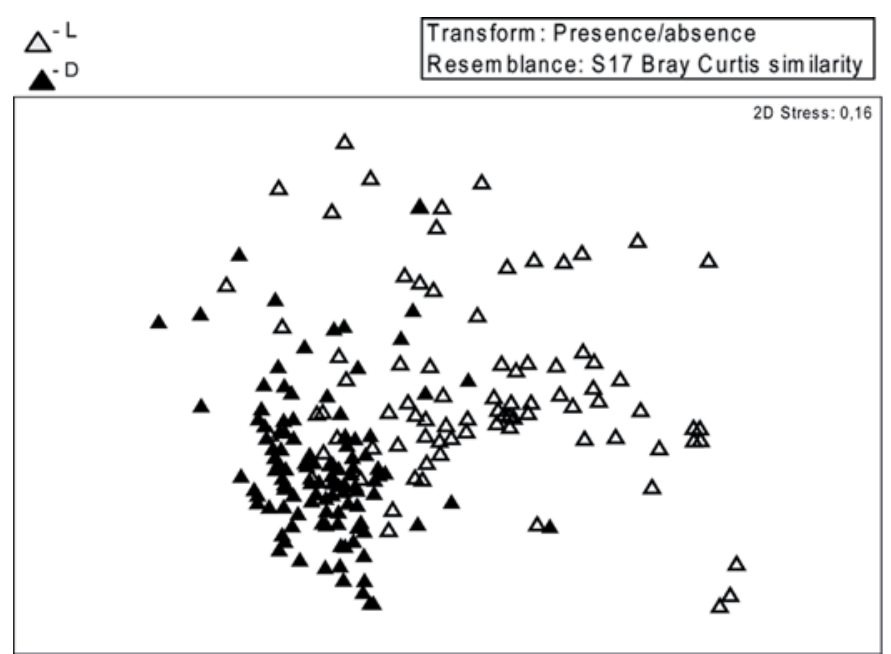

Fig. 2. - The diagram represents a NMDS graph (Non-metric multidimensional scaling; so axes are represented without units). Similarity between samples with dead and living foraminifera, from the study, was evaluated by the Bray Curtis index applied to a presence/ absence matrix. The results are presented in this NMDS graph.

Fig. 2. -El diagrama representa un gráfico NMDS (escalamiento multidimensional no métrico; ejes que se representan sin unidades). La similitud entre las muestras de foraminíferos vivos y muertos, en el estudio, se evaluó por el índice de Bray Curtis que se aplicó a una matriz de presencia/ausencia. Los resultados se representan en esto gráfico NMDS.

Haynesina germanica ( $<21 \%)$, Quinqueloculina seminulum (<13\%), Globocassidulina rossensis $(<11 \%)$, Cribrostomoides jeffreysi $(<8 \%)$, Bulimina elongata/gibba $(<8 \%)$, Bolivina pseudoplicata $(<8 \%)$, Tiphotrocha concava $(<7 \%)$, Lepidodeuterammina ochracea $(<7 \%)$, Elphidium gerthi $(<7 \%)$, Bolivina ordinaria $(<7 \%)$, Reophax dentaliniformis $(<7 \%)$, Elphidium articulatum $(<6 \%)$, Neoconorbina parkerae $(<6 \%)$, Elphidium crispum $(<6 \%)$ and Hanzawaia nitidula $(<5 \%)$.

The most abundant species in the living assemblage of the Ria de Aveiro inlet and surrounding areas are $L$. ochracea $(<52 \%)$, E. articulatum $(<52 \%)$, H. germanica $(<40 \%)$, A. tepida $(<40 \%)$, L. lobatula $(<34 \%)$, T. concava $(<34 \%)$, P. mediterranensis $(<28 \%)$, B. ordinaria $(<25 \%)$, Q. seminulum $(<20 \%)$, C. ungerianus $(<19 \%)$, E. gerthi $(<14 \%)$, B. pseudoplicata $(<13 \%)$, Trochammina haynesi $(<13 \%)$, Elphidium oceanensis $(<11 \%)$, Remaneica helgolandica $(<11 \%)$, G. rossensis $(<9 \%)$, B. elongata/gibba $(<8 \%)$, Elphidium williamsoni $(<6 \%)$, Quinqueloculina lata $(<5 \%)$ and Septotrochammina gonzalezi $(<5 \%)$.

Many of the individuals of these benthic foraminifera species reflect the effect of transport originating from hydrodynamic processes. Some species that live on the oceanic bottom are resuspended, by wave action, and introduced in the lagoon, swept up by tidal currents. Bolivina/Brizalina spp. are typical oceanic species, however B. ordinaria and B. pseudoplicata can be found alive in muddy sediments of inner lagoonal areas. Q. seminulum can also be found alive in inner lagoonal areas, away from the rivers direct influence. Species such as $L$. ochracea, $T$. concava, T. haynesi, $R$. helgolandica and $S$. gonzalezi can be found in the continental shelf environment. This group of species is an important member of the living assemblages under active currents in the S. Jacinto Channel and in the inlet. However, they are poorly represented in the dead assemblage, since their agglutinated tests are fragile and easily destroyed after the death of the organism. In fact several species that comprise the dead assemblage are not found in the living assemblage of the study area (as can be seen in Appendix 2).

Some of the species found alive in the Ria de Aveiro entrance, such as L. lobatula, P. mediterranensis, C. ungerianus, E. gerthi, G. rossensiss, B. elongata/gibba and $Q$. lata are not found in inner lagoonal zones. Some species are rare in the living assemblage of the lagoon entrance or appear only in the dead assemblage, such as Biloculinella depressa, Bolivina/Brizalina (excluding B. ordinaria and B. pseudoplicata), Bulimina/Globobulimina, Cancris auriculus, Cassidulina/Globocassidulina, Cassidulinoides bradyi, Discorbs mira, Epistominella vitrea, Gavelinopsis praegeri, Glabratella chasteri, Hanzawaia nitidula, Lamarckina haliotidea, Laryngosigma hyalascidia, Laryngosigma lactea, Laticarinina altocamerata, Lenticulina atlantica, Lenticulina orbicularis, Neoconorbina parkerae, Nonion fabum, Nonionoides mexicanus, Nonionoides pauperatus, Paumotua terebra, Rectuvigerina phlegeri, Spiroloculina excavata, Stainforthia complanata, Stainforthia feylingi, Stainforthia fusiformis, Stainforthia loeblichi, Trifarina angulosa and Valvulineria bradyana. In accordance with the above, the percentage of damaged empty tests of benthic foraminifera belonging to these species, were considered as having been imported from the adjacent shelf environments and introduced into the Aveiro lagoon. This group was referred to as 'oceanic specimens', as was previously noted above.

\section{Statistical analyses}

In general, the spatial distribution of sediment grain size, and its composition in coastal lagoons, may essentially be related to tidal energy, storm-dominated sorting and sediment sources (Anthony and Héquette, 2007). In order to better understand how these forcing factors control the sedimentary processes in the study area, and considering the large number of variables to be analysed, it was considered advantageous to group selected variables with similar occurrence. For this purpose, cluster analysis was performed using Pearson correlation. Several methods to carry out the data agglutination were used; the results obtained with Ward's method were considered 
coherent, since the variables included in each group have maps with identical distribution patterns.

The results of this analysis, represented in the dendrogram shown in Fig. 3, establish three main groups of variables:

Group 1 is composed of the sedimentary fraction $>250 \mu \mathrm{m}$; K-feldspar, quartz, and median grain size. This group is associated with coarser sediments, enriched in quartz and feldspars. This kind of sediment can be found mostly in S. Jacinto Channel and in the lagoon inlet (Fig. 4).

Group 2 includes the sedimentary fraction $125-250 \mu \mathrm{m}$, plagioclase, carbonates, 'oceanic specimens', Shannon index values and concentrations of $\mathrm{K}, \mathrm{Rb}, \mathrm{Ba}, \mathrm{P}, \mathrm{Ca}$, and Sr. Contents of fine sand fractions $(125-250 \mu \mathrm{m})$ have higher positive correlations $(p>0.05)$ with $\mathrm{K}$ (PC 0.81 ), $\mathrm{Rb}(\mathrm{PC} 0.76)$ and $\mathrm{Ba}(\mathrm{PC} 0.75)$; its correlation with $\mathrm{P}$ is lower but also positive (PC $0.45, p>0.05$ ). Fig. 5 represents maps of distribution of a) fine sand and b) $K$, c) Ba and, d) $\mathrm{P}$. The distribution pattern of $\mathrm{Rb}$ is not presented in this figure, because it is similar to that of $\mathrm{Ba}$ (PC 0.98) and $\mathrm{K}$ (PC 0.96). 'Oceanic specimens' have positive correlations (PC 0.78) with the Shannon index. Both these variables also have positive correlations $(p>0.05)$ with carbonates, $\mathrm{Ca}$ and Sr. Fig. 6 includes the distribution maps of the following variables: a) 'oceanic specimens', b) Shannon index values $(\mathrm{H})$, c) carbonates and, d) Ca. The map of $\mathrm{Sr}$ is not shown in this figure; its distribution pattern is similar to that of $\mathrm{Ca}$ since they have high and positive correlation (PC 0.89, $p>0.05$ ). 'Oceanic specimens' reach higher percentages in the western side of Mira channel, close to the south jetty, and near the head of the north jetty.

Group 3 contains the phyllosilicates, the sedimentary fractions $<63 \mu \mathrm{m}$ and $63-125 \mu \mathrm{m}$, foraminifera density and $\mathrm{Cr}, \mathrm{Ti}, \mathrm{Mn}, \mathrm{La}, \mathrm{Zr}, \mathrm{Ce}, \mathrm{Th}, \mathrm{V}, \mathrm{Na}, \mathrm{Al}, \mathrm{Li}, \mathrm{S}, \mathrm{Mg}$ and $\mathrm{Zn}$. The variables of this group are represented in Fig. 7 by the distribution maps of a) phyllosilicates, b) Ti, c) very fine sand fraction $(63-125 \mu \mathrm{m}), \mathrm{d}) \mathrm{La}, \mathrm{e})$ foraminifera density, and f) Al. In general, these variables reach higher values in the western side of the Mira channel, close to the south jetty and near the north jetty head, where sediments are finer.

Cluster analysis in mode Q, using Euclidean distances and Ward's method for data agglutination, was applied to a normalised data matrix, with the aim of grouping stations with bottom sediments of similar characteristics. The variables used in the dendrogram of Fig. 3 (cluster analysis in mode R) were also considered in this analysis. Fig. 8 presents the results of this analysis, identifying each group of stations with similar bottom sediment characteristics by a different shade of grey.

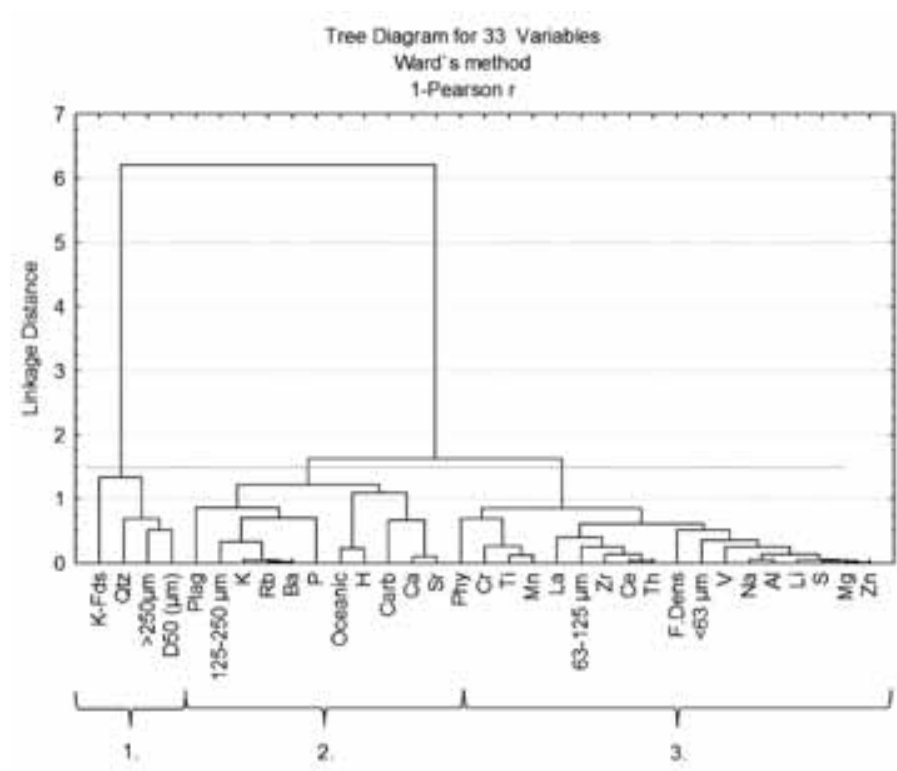

Fig. 3. - Cluster analysis based on some selected data, using Pearson correlation and Ward's method to perform the data agglutination. Analysed variables: i) concentrations of $\mathrm{Al}, \mathrm{Ba}, \mathrm{Ca}, \mathrm{Ce}, \mathrm{Cr}, \mathrm{K}$, La, Li, Mg, Mn, Na, P, Rb, S, Sr, Th, Ti, V, Zn and Zr); ii) values of sediments' mean grain size (D50), by percentage: fine fraction $(<63 \mu \mathrm{m})$, very fine sand $(63-125 \mu \mathrm{m})$, fine sand $(125-250 \mu \mathrm{m})$, medium sand fraction to gravel fractions $(>250 \mu \mathrm{m})$; iii) percentage of $\mathrm{K}$-feldspar (K-Fds), quartz (Qtz), plagioclase (Plag), carbonates (Carb), phyllosilicates (Phy); iv) Shannon Index values $(\mathrm{H})$, percentage of oceanic specimens (Oceanic) and foraminifera density (F.Dens). Three main groups of variables can be considered with a cut off at 1.5.

Fig. 3. - El análisis clúster basado en algunos datos seleccionados, utilizando la correlación de Pearson y el método de Ward, para realizar la aglutinación de datos. Análisis de las variables: i) las concentraciones de Al, Ba, Ca, Ce, Cr, K, La, Li, Mg, Mn, Na, P, Rb, S, $\mathrm{Sr}$, Th, Ti, V, Zn y Zr); ii) Valores del tamaño mediano del grano de los sedimentos (D50), porcentaje de: fracción fina $(<63 \mu \mathrm{m})$,arena muy fina $(63-125 \mu \mathrm{m})$, arena fina $(125-250 \mu \mathrm{m})$, fracción arena media a las fracciones de grava $(>250 \mu \mathrm{m})$; iii) el porcentaje de feldespato potásico (K-Fds), cuarzo (Qtz), plagioclasa (Plag), carbonatos (Carb), filosilicatos (Phy); iv) Los valores del índice de Shannon $(\mathrm{H})$, el porcentaje de muestras oceánicas (Oceanic) y densidad de foraminíferos (F.Dens). Se pueden considerar tres grandes grupos de variables para el corte a una distancia de 1,5.

\subsection{Suspended sediments}

\section{Suspended sediment concentrations}

Suspended sediment concentrations (SSC) varied between $7.7 \mathrm{mg} . \mathrm{l}^{-1}$ and $105.6 \mathrm{mg} . \mathrm{l}^{-1}$. Despite SSC generally increasing from the surface to the bottom, the differences between surface, middle-depth and bottom water samples were very small, during the sampling period in the studied sites (Fig. 1).

Therefore, for each studied depth (surface, middle and bottom), averages of the SSC in each station were determined during neap and spring tides of winter and summer oceanographic regimes, for different tidal phases (flood, 

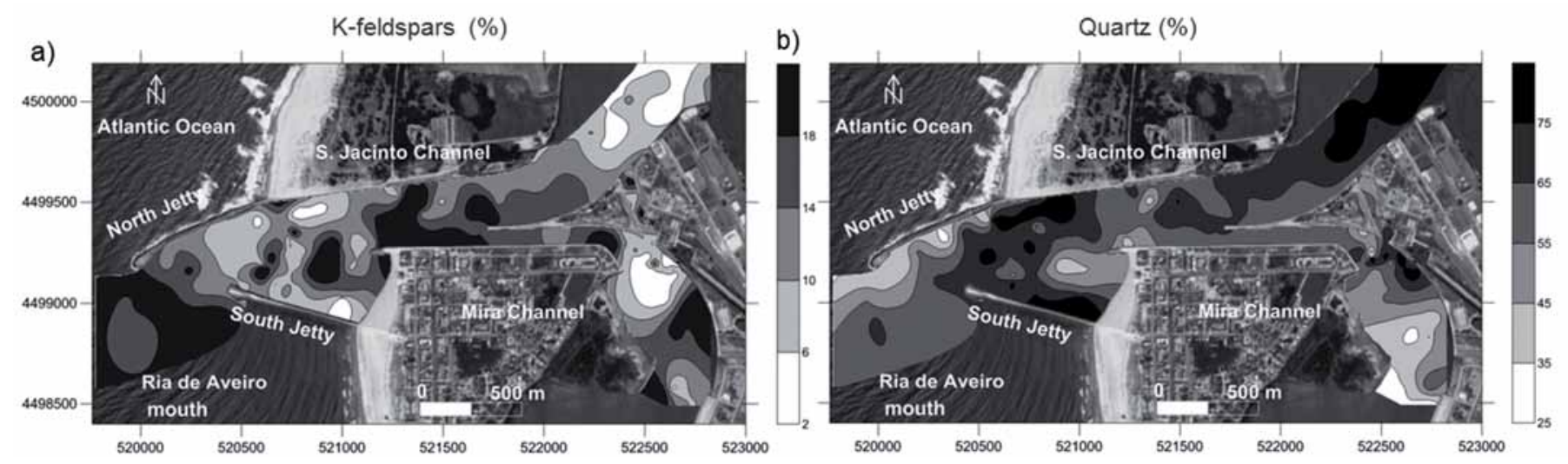

c) Sediments fraction $>250 \mu \mathrm{m}(\%)$

d)
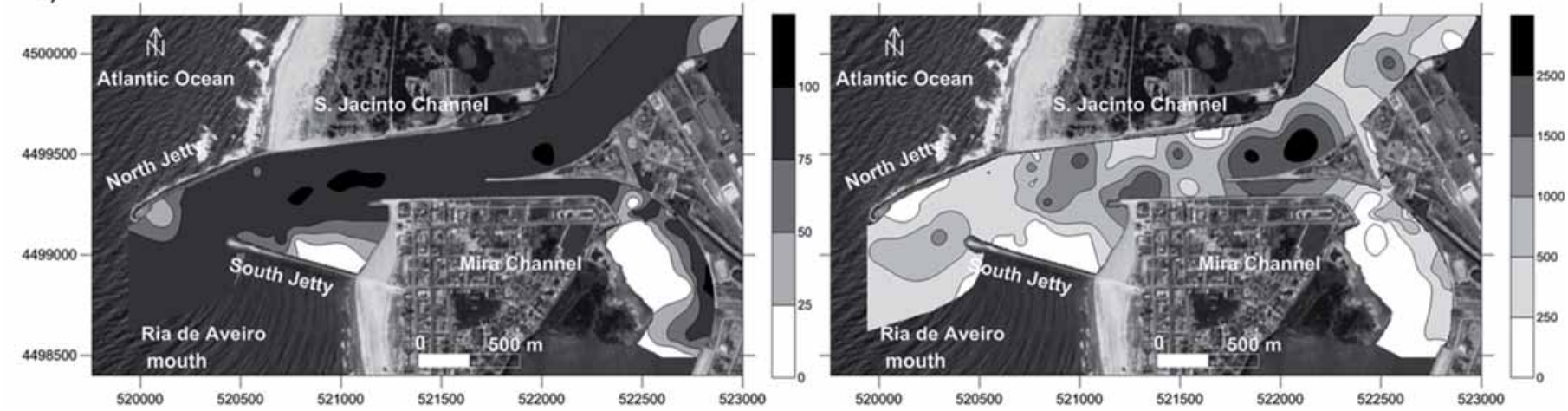

Fig. 4. - Distribution maps of: a) $\mathrm{K}$-feldspars (\%); b) quartz (\%); c) sediment fraction $>250 \mu \mathrm{m}(\%)$; d) sediment median grain size ( $\mu \mathrm{m})$.

Fig. 4. - Mapas de distribución de: a) K-feldespatos (\%); b) cuarzo (\%); c) fracción de sedimentos $>250 \mu$ m (\%); d) tamaño mediano del grano de los sedimentos $(\mu \mathrm{m})$.

high tide, ebb and low tide). The results are shown in Fig. 9. Values plotted in this figure show that the highest SSC were recorded during winter in the inlet and in the S. Jacinto Channel during different tidal phases. In the inlet, the highest SSC occur more frequently during the flood phase, whereas in the S. Jacinto and Mira Channels these occur normally during ebb and low tides.

\section{Suspended sediment grain size and mineralogy}

Suspended particulate matter (SPM) in bottom water during the flood phase mostly consists of fine fraction $(<63 \mu \mathrm{m} ;>70 \%)$ in all the study area along the year, independently of winter or summer, spring or neap tides, (Fig. 10a). The contents of silt are similar in bottom water winter spring tides, during flood and ebb (Fig. 10b).

In the analysed water samples, the sediment median grain sizes (D50) of SPM, varies between $10-44 \mu \mathrm{m}$, also showing the predominance of silt-sized materials. SPM median grain size, in bottom water samples, during winter spring tide, reached higher values during the flood and high tide, in the S. Jacinto Channel, and during the ebb phase, in the Mira Channel (Fig. 10c).

The graphs for stations B1 (lagoon inlet) and MC (Mira Channel) were selected to characterize the mineralogical composition of SPM in bottom water, during flood in summer and winter spring and neap tides, in all the stations, since they have similar results (Fig. 10d). The predominant mineral in the composition of the SPM is quartz (max. 70\%), followed by phyllosilicates (max. $42 \%$ ) and by plagioclase (max. $18 \%$ ) and $\mathrm{K}$-feldspars (max. 27\%). Carbonates, mainly calcite, are also present (max. 10\%).

\section{Discussion}

In all types of coastal environments it is common to find several classes of bed sediments due to the transport processes operating on regional and local scales, and to different sediment sources, either coming from the continent or from the sea (Waeles et al., 2007). Surface sediments from the Ria de Aveiro inlet and surrounding areas show considerable differences in terms of grain size and geochemical, mineralogical and microfaunal composition (Figs. 4-7). Bottom sediments of the lagoon inlet, S. Jacinto Channel and eastern side of the Mira Channel are composed mainly of 'poorly sorted' coarse sand and gravel. However, in the western side of the Mira Channel and at the head of north jetty, which are more sheltered areas, 'moderately well sorted' and 'well sorted' fine sand and coarse silt can be collected. Thus, several grain popu- 
a)

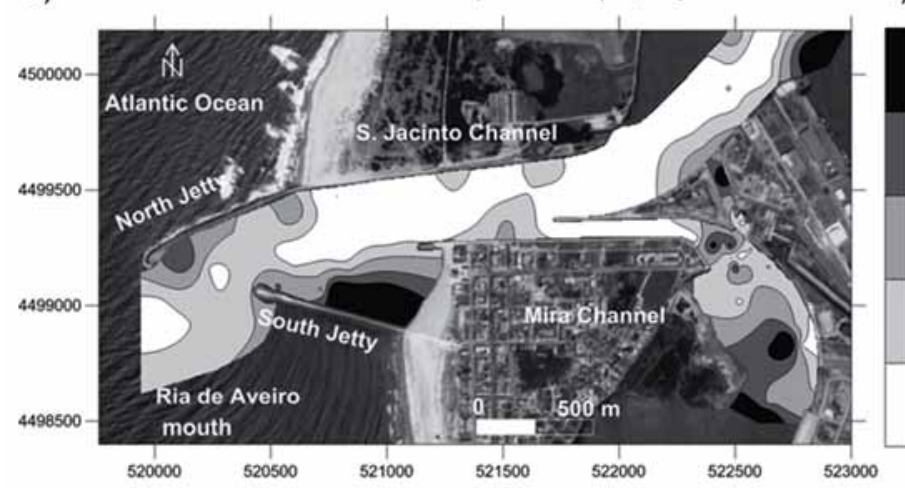

c)

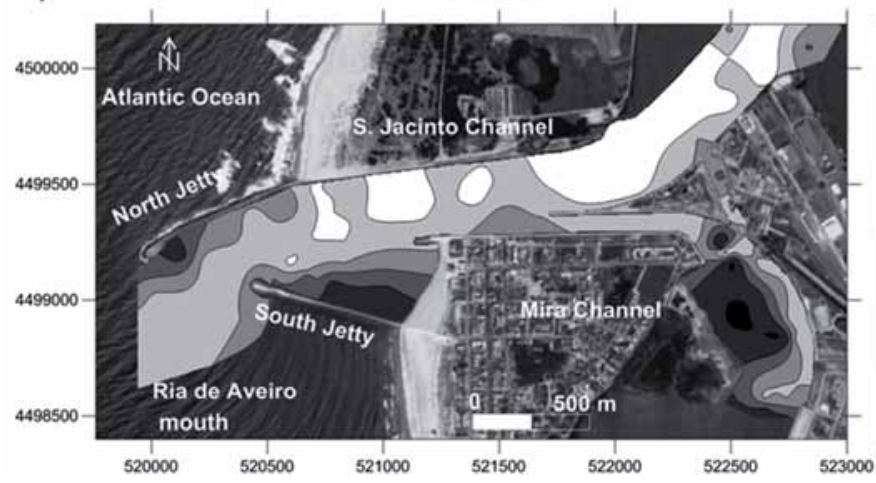

b)

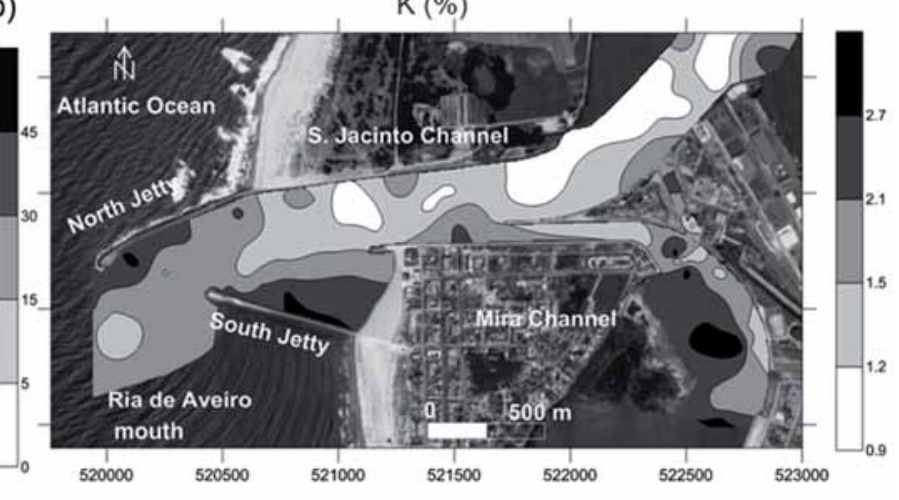

d)

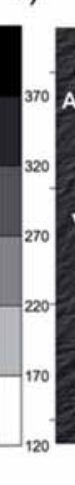

$\mathrm{P}(\%)$

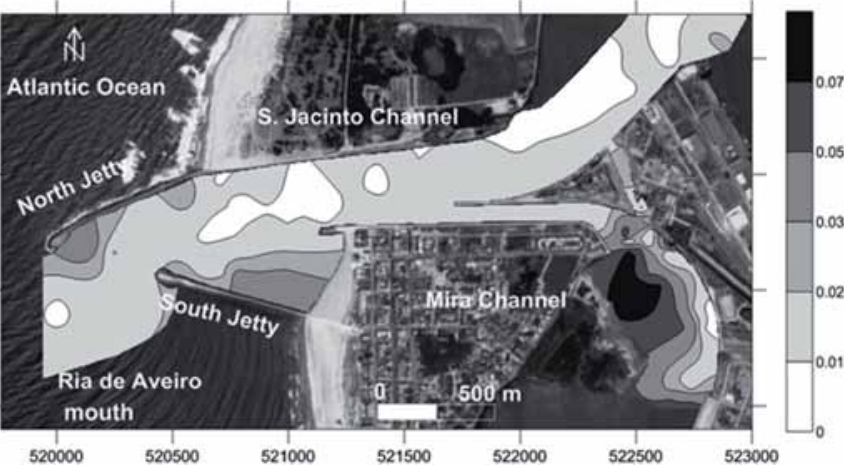

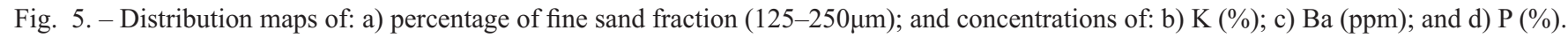
Fig. 5. - Mapas de distribución de: a) porcentaje de la fracción de arena fina (125-250 $\mu \mathrm{m})$; y de las concentraciones de: b) K (\%); c) Ba (ppm); y d) P (\%).

lations can be identified in the bottom sediments of the studied area, which are related to different processes of sediment transport.

\subsection{Identification of areas of net erosion}

Different suspension patterns for SSC and median grain size were observed in the whole of the studied area (Figs. 9 and 10c, respectively). The highest SSC have been recorded in the S. Jacinto Channel during the flood of the winter neap tide (Fig. 9). During this period SSC in the lagoon inlet were lower. However, an opposite pattern was expected, this is, higher concentrations of suspended sediments in the lagoon entrance, due to the supply of sediments from the nearby oceanic areas and the progressive reduction of concentrations towards inner lagoonal areas (as a result of the progressive deposition of sediments). The fact that the highest recorded SSC values came from the S. Jacinto Channel may be a consequence of the local resuspension of sediments. This means that erosion is occurring on the bottom of the lagoon inlet channel and along S. Jacinto Channel.

Further evidence of the possible resuspension of sediments from the bottom of the lagoon entrance area is the higher values of SSC during low winter spring tide when compared with other tidal phases, in the lagoon inlet and the S. Jacinto Channel (Fig. 9). This may be also related to erosion of the bottom of these channels or of the edges of the nearby channels. The coarser sediments in bottom water SPM (due to the relatively higher content of the sand fraction; Fig. $10 \mathrm{c}, \mathrm{b}$ ) during flood and high winter spring tide, when compared with the inlet and the Mira channel, may also be indicative of erosion of bottom sediments in this area (Fig. 10c).

These inferences are supported by the findings of Plecha et al. (2010). These authors identified zones of scouring and erosion by comparing the bathymetric evolution, between 2002 and 2005, in the lagoon inlet and the S. Jacinto Channel. Their results show intense erosion between the two breakwaters.

In fact this erosional nature shows up in the characteristics of the bottom sediments found in central areas of the S. Jacinto Channel, the lagoon inlet and close to the north jetty. Here, very strong tidal currents prevail, where, for example, the magnitude can be in excess of $2 \mathrm{~ms}^{-1}$ at the centre of the inlet (Vaz et al., 2009). In these areas, coarser bottom sediments composed mostly of quartz and feldspars (Fig. 4b, a), with low concentrations of geogenic chemical elements (such as those included in cluster 3 of Fig. 3 and represented in the distribution maps of 
a)

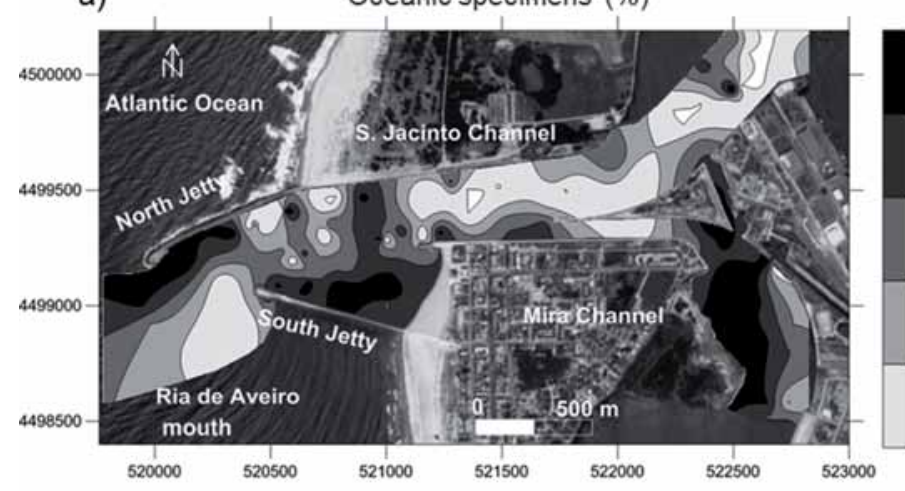

c)

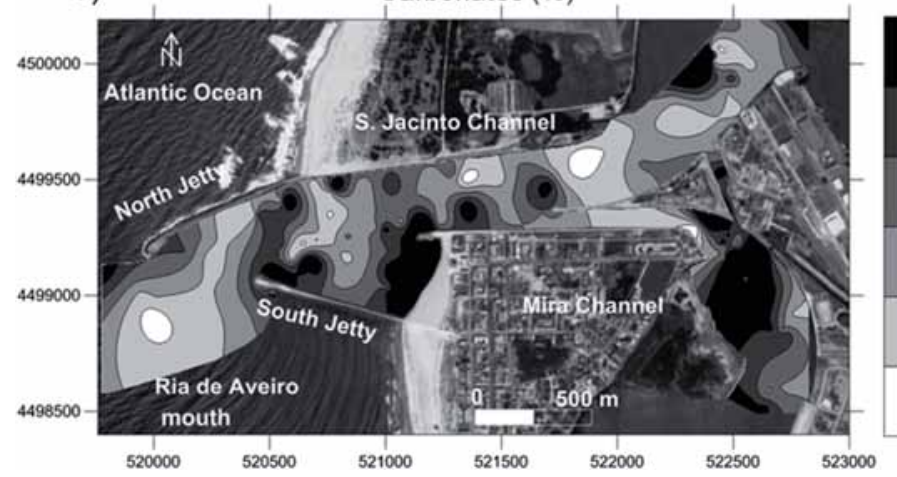

b)

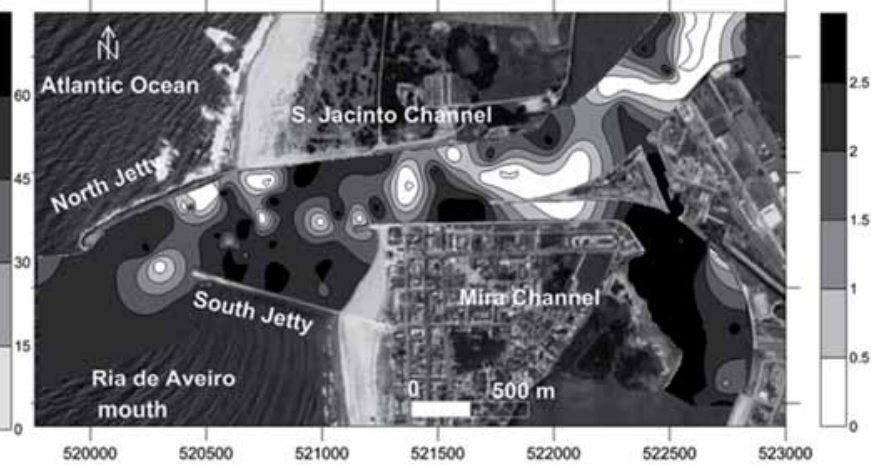

d)

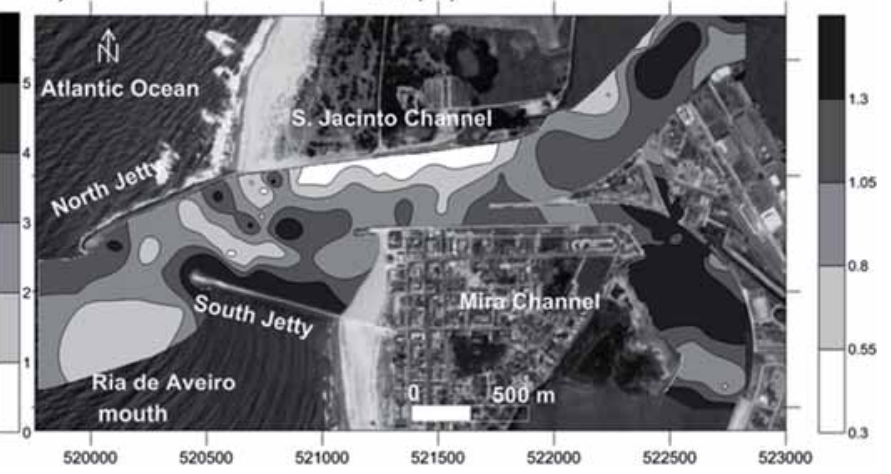

Fig. 6. - Distribution maps of: a) 'oceanic specimens' (\%); b) Shannon index values (H); c) carbonates (\%) and; d) Ca (\%).

Fig. 6.-Mapas de distribución de: a) 'oceanic specimens' (especies oceánicas) \%); b) valores del índice de Shannon (H); c) carbonatos (\%); $\mathrm{y}$ d) $\mathrm{Ca}(\%)$.

Ti, La and Al, in Figs. 7b, 7d and 7f, respectively) and foraminifera tests (Fig. 7e), can be found, all a sign of such strong erosive character. This erosional character is represented by white and lighter shaded areas in Fig. 8, which map an integrated synthesis of the results, comparing the sedimentary characteristics of the studied stations.

\subsection{Identification of areas of net deposition}

According to Waeles et al. (2007), grain size and compositional distributions can be related to bottom shear stress, and can also vary depending on the relative energy of the waves and currents. Tidal currents, waves, and compensatory flows in response to storm wind are the most important forces driving the transport of sediments in the lagoon (according to Lopes et al., 2006).

Because of the relatively high settling velocities of sand grains compared to clay-sized particles, their transport adjusts very quickly to dynamic variations. The response of foraminifera tests to the stress of currents can however be much faster than that of quartz grains of equivalent sizes. This is because the former have the dimension of sand particles but have lower density than quartz grains. The hydraulic behaviour of foraminifera tests explains the dissimilarity between the majority of the studied samples when looking at the composition of the living and dead assemblages (Fig. 2). Some species found in the area, such as P. mediterranensis, L. ochracea, T. concava, T. haynesi, $R$. helgolandica and $S$. gonzalezi, live attached to sand grains. When the organism dies, it is easily removed and transported to other areas by the strong tidal currents. Moreover the agglutinated specimens can easily be destroyed by desegregation. Thus the increased density of foraminifera in bottom sediments indicates the occurrence of zones of sediment deposition (Fig. 7e).

Hydrodynamic processes operating on areas of erosion further lead to segregation of silt and very fine sand fraction which are rapidly evacuated from the most hydrodynamic areas located in the inlet and S. Jacinto Channel, and may be trapped in tidal embayments, such as the zone located in the western side of Mira Channel or in more protected areas, such as the one close to the south jetty. The lower-energy bottom currents, in these areas, allow the deposition of finer sediments with a higher content of phyllosilicates and carbonates, including foraminifera tests, and higher concentrations of geogenic chemical elements (see Fig. 7). Both these areas are also marked by higher concentrations of $\mathrm{K}, \mathrm{Ba}, \mathrm{P}$ (Figs. 5b, 5c, 5d) and $\mathrm{Rb}$ (Cluster 2, Fig. 3), which may indicate a larger oceanic influence. Other proxies for this kind of source are 
the percentage of 'oceanic specimens' in the sediments (Fig. 6a). That foraminifera tests that are provided by the oceanic environments is one of the reasons for the increase in diversity (higher Shannon index values; Figs. $6 a, b)$. Evidence of sediments originating from oceanic sources is also found in the SSC measured, for instance, during the flood tidal phases (Fig. 9), suggesting entry into the lagoon of materials provided from the adjacent continental shelf.

The deposition processes may be more important on the western side of the Mira Channel when compared to the zone close to the south jetty. This side of the Mira channel is flanked by a tidal sandy mud flat. The supply of sedi- ment to this area could be significant as indicated by the SSC. The sediment transport and deposition, in this area, may be mainly governed by the characteristic cyclic tidal flow. Sediment deposition is favoured by periods of low current velocities around slack tide.

Areas of net deposition of sediments are represented by darker shaded zones in Figure 8, which map an integrated overview of the results.

\subsection{Sediment import from the continental shelf}

Suspended sediments transported landward, through the lagoon entrance, during the flood, may essentially a)

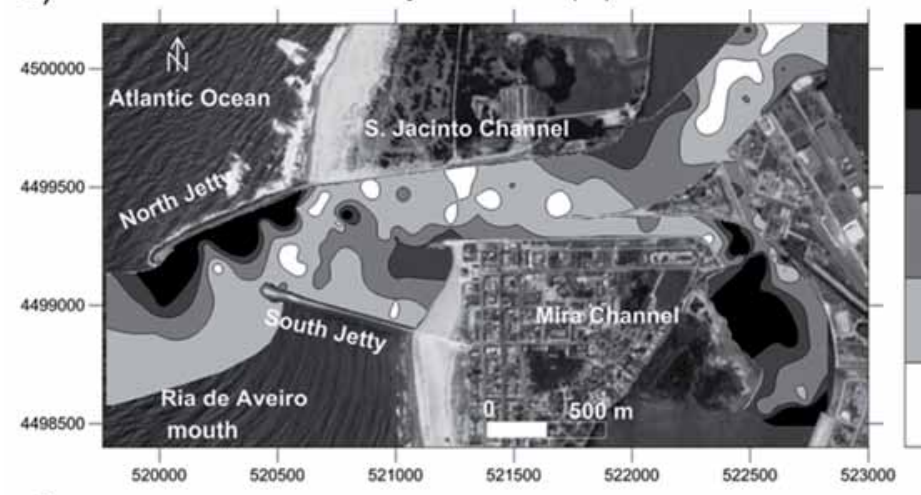

c)

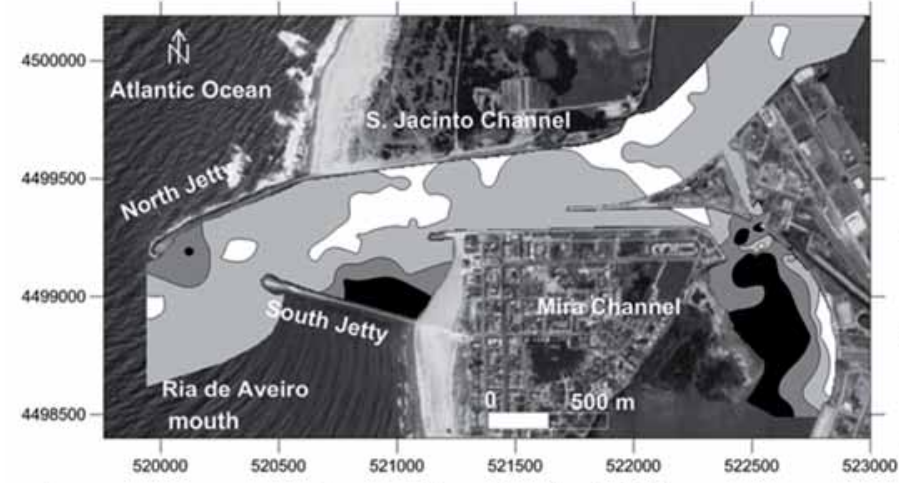

b)

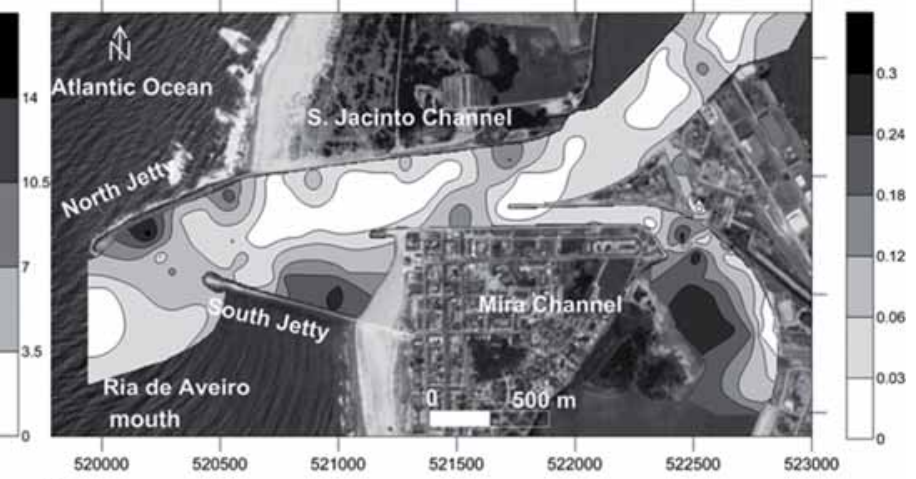

d)

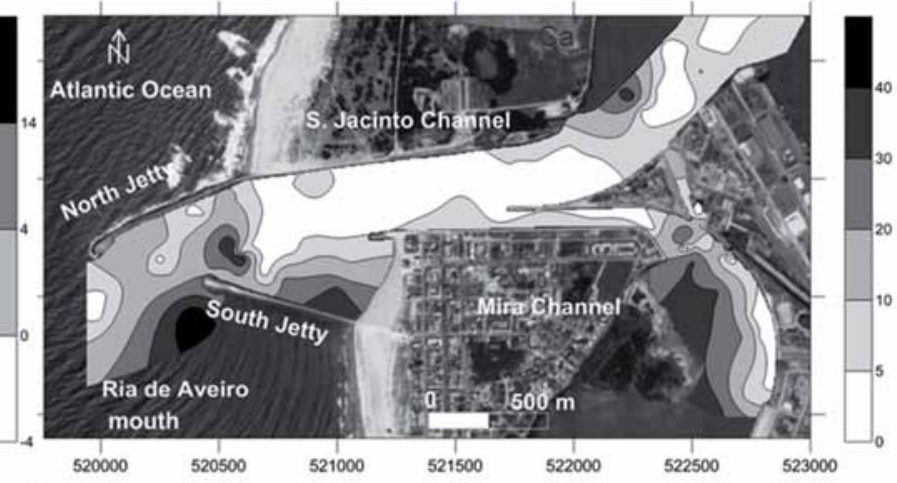

f)
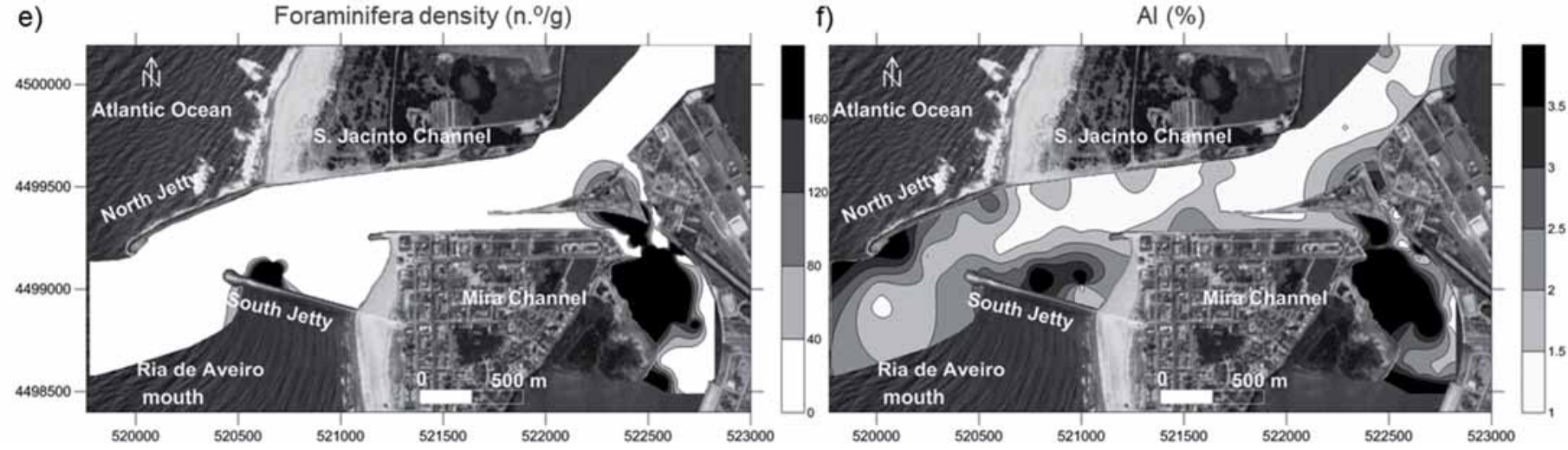

Fig. 7. - Distribution maps of: a) phyllosilicates (\%), b) Ti (ppm), c) fine sand fraction (63-125 $\mu \mathrm{m}$; \%); d) La (ppm); e) foraminifera density (n. ${ }^{\circ} / \mathrm{g}$ ) and; f) $\mathrm{Al}(\%)$.

Fig. 7. - Mapas de distribución de: a) filosilicatos (\%); b) Ti (ppm); c) de la fracción arena fina (63-125 $\mu$ m; \%); d) La (ppm); e) la densidad de los foraminíferos (n. $\%$ g); y f) $\mathrm{Al}(\%)$. 


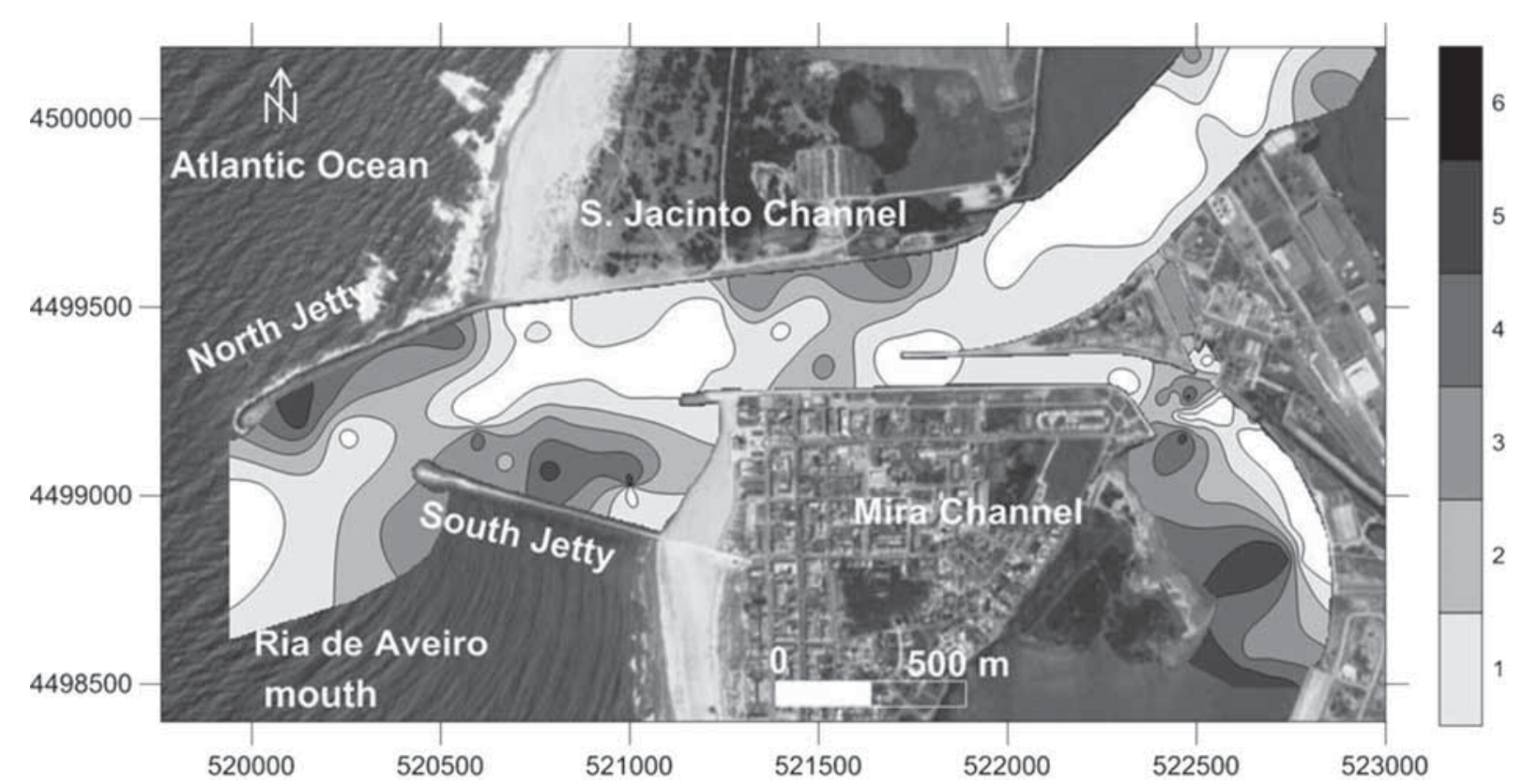

Fig. 8. - Distribution map of groups of stations-samples established by cluster analysis in mode Q, considering the variables used in the dendrogram included in Figure 3 (cluster analysis in mode R), using Pearson correlation and Ward's method to perform data agglutination.

Fig. . 8. - Mapa de distribución de los grupos de estaciones de muestreo establecidas mediante el análisis clúster en modo Q, teniendo en cuenta las variables utilizadas en el dendrograma incluido en la Figura 3 (análisis clúster en modo R), utilizando la correlación de Pearson y el método de Ward para agrupar los datos.

originate from the nearby continental shelf. The values of SSC, through the inlet lagoon channel, during the flood, are similar in winter and summer, spring and neap tides and are not higher than other sites (Fig. 9). It was expected that higher SSC values would be recorded in the inlet channel during the winter, since, as according to Vitorino et al. (2002a, b), the hydrodynamic conditions are stronger during this season, and storms linked with southerly winds are more frequent. In addition, rainfall is also usually more intense leading to more frequent flooding of rivers in this season. During winter, the currents on the shelf are directed toward the north (poleward flow) due to the weakening of the northerly winds or the prevalence of southerly winds (Vitorino et al., 2002a, b). Otherwise the main sources of sediments for this area are located to the north (Dias et al., 2002). Sediments are being transported to this area of continental shelf by the littoral drift and are mainly supplied by the river Douro, at north of this region (Abrantes and Rocha, 2007 and references herein). However, during the winter the sediments launched onto the continental shelf by this river are transported by the oceanic currents northward, providing little contribution to the study area.

During the spring-summer oceanographic regime, the strengthening of northerly winds induces currents flowing towards the south, onto the continental shelf, favouring the southward littoral drift (Dias et al., 2002). These seasons are in general dryer and the river flow is lower however. On the other hand, the layout of the Ria de Aveiro breakwaters does not favour a large inflow of sediments into the lagoon. Thus the contribution of sediment from the ocean to the lagoon should be not very high.

\subsection{Export of fine-grained material to the shelf}

Suspended sediment concentrations (SSC) flowing seaward, during the ebb (Fig. 9), are higher during the winter season. Picado et al. (2010) and Dias et al. (2000) recorded higher current velocities on ebb than on flood. During ebb, as expected, the sediment concentration may not be as influenced by wave climate, since the tidal flow is transporting sediments from the marsh located in inner lagoonal areas to the ocean. Thus, the higher SSC verified during winter, for the periods of ebb and even the low tide, can be explained by the availability of sediments during this season which, in turn, can be related to increased rainfall and river runoff.

Most of the sediment introduced into the lagoon by the rivers is silt and clay, which is deposited in low hydrodynamic areas such as intertidal flats and salt marshes (Teixeira, 1994). During the winter season stronger tidal currents and strong wind stress, may also contribute to the higher SSC along the main channels, due to higher bottom shear stresses that favour sediment remobilization on channels and marsh surfaces and the advective transport of sediments (Lopes et al., 2006). The ebb jet 
Suspending Sediments Concentrations $\left(\mathrm{mg} \cdot \mathrm{l}^{-1}\right)$
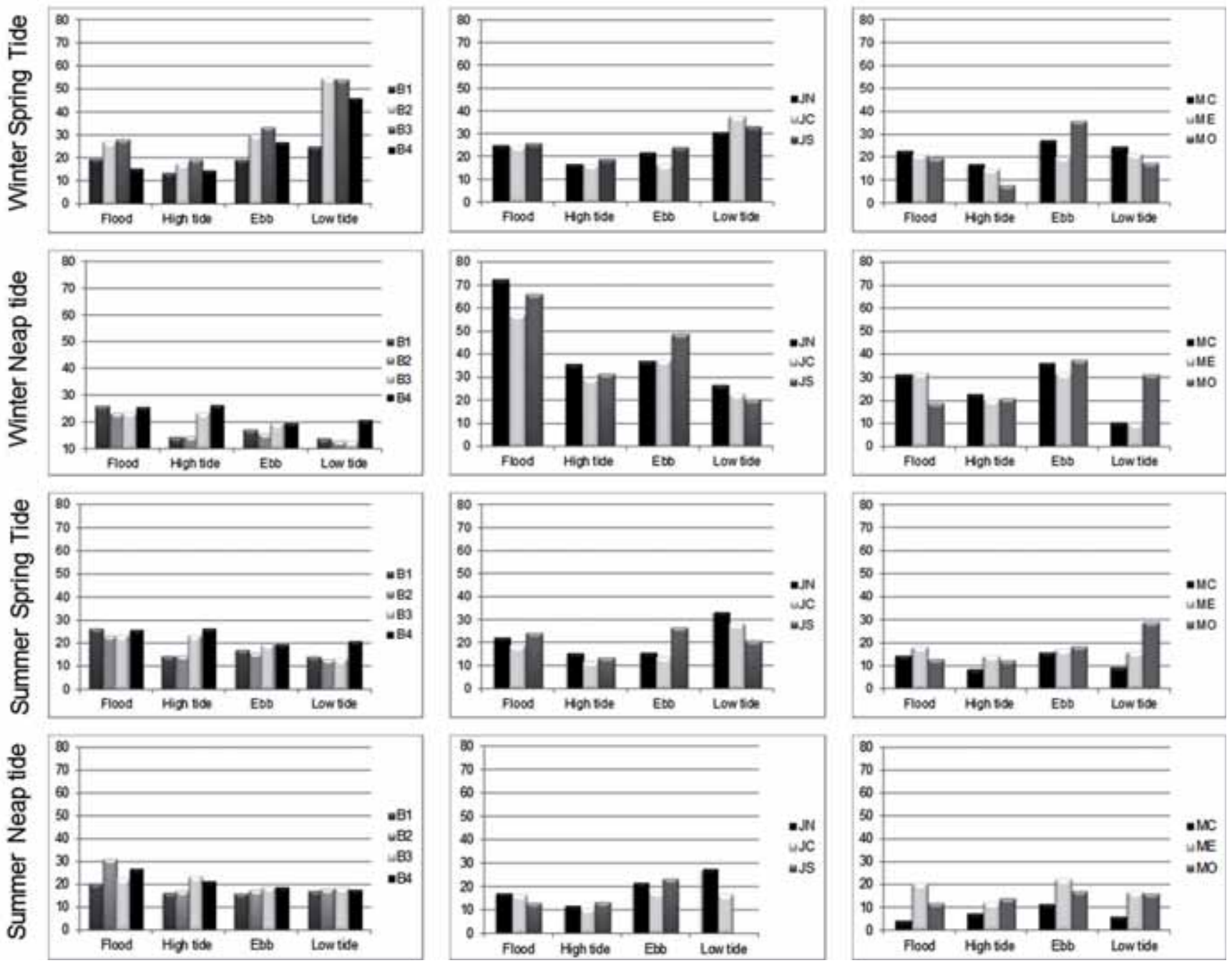

Fig. 9. - Mean (of surface, middle and bottom water samples) suspended sediment concentrations (mg. $1^{-1}$ ), during winter and summer, spring and neap tides, in the three sampling areas (signed in Fig. 1): Ria de Aveiro inlet - B1, B2, B3 and B4; S. Jacinto Channel - JN, JC and JS and; Mira Channel - MC, ME and MO.

Fig. 9. - La media (de muestras de agua en superficie, medio y fondo) de las concentraciones de sedimentos en suspensión (mg..$\left.^{-1}\right)$, durante las mareas vivas y muertas de invierno y de verano, en las tres áreas de muestreo (indicadas en la Fig. 1): entrada de la Ría de Aveiro B1, B2, B3 y B4; Canal de S. Jacinto - JN, JC y JS; Canal de Mira - MC, ME y MO.

extends into the shelf as shown by numerical simulations of the ocean circulation in the vicinity of the inlet (Silva et al., 2006), transporting mostly muddy sediments, composed mainly of quartz and phyllosilicates with a lower content of $\mathrm{K}$-feldspars, plagioclase and calcite as demonstrated in this work (Fig. 10).

\section{Conclusion}

The integration of granulometric, mineralogical, geochemical and microfaunal data of bottom sediment from the area around the Ria de Aveiro entrance allowed the identification of the main areas of vulnerability and protection for the physical structures (Fig.8), which maintain the artificial entrance to the Ria de Aveiro open and geographically stable. The most protected zones, with a tendency for sediment accretion, are located, for instance, at the western side of the Mira Channel, close to the south jetty and near the head of north jetty. Areas with an erosive character are located along the centre of the inlet and the S. Jacinto Channels. The analysis of SSC also provides evidence that bottom sediments in some zones of these channels are being resuspended. Thus it is possible to assume that the erosive action of tidal currents may have its origin in the natural sinking of these channels. Furthermore the obtained results in this study also raise a concern: some segments of the north jetty may be more vulnerable to erosion. Damage due to strong stresses caused by intense tidal currents in the area is, as such, a real possibility. 
a) Bottom Water SPM Grain Size during the Flood in Summer and Winter Spring and Neap Tides (Percentage of Sedimentary Fractions)
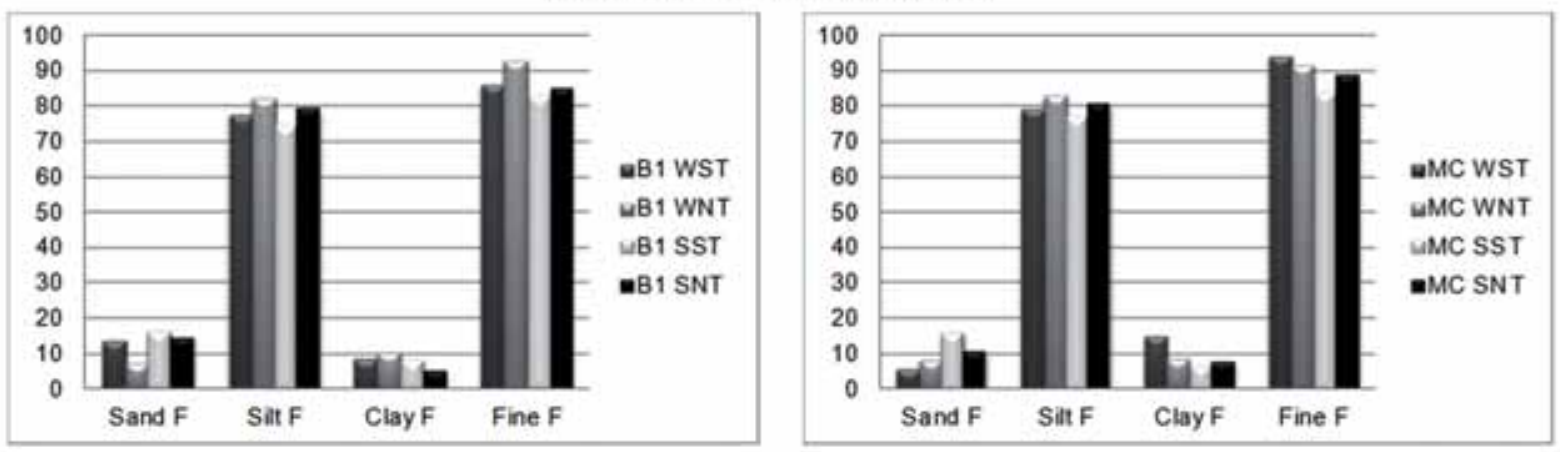

b) Percentage of Sedimentary Grain Size Fractions in Bottom Water c) SPM Median Grain Size ( $\mu$ m), in Bottom Water SPM, during SPM, during Winter Spring Tide
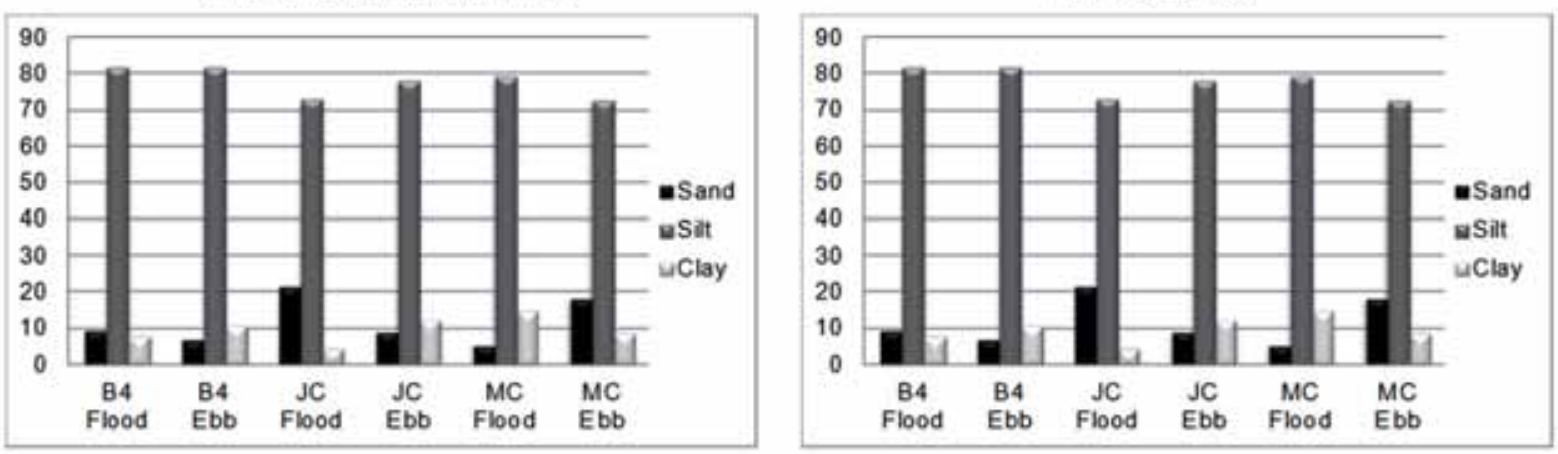

d) Bottom Water SPM Mineralogy during the Flood in Summer and Winter Spring and Neap Tides (Percentage of Minerals)
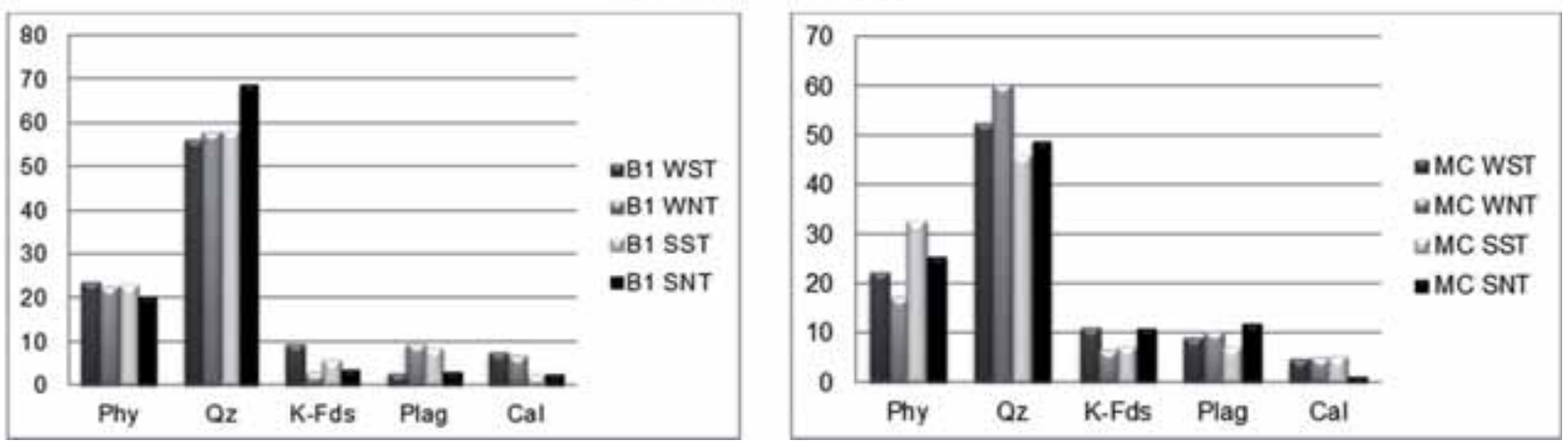

Fig. 10. - a) Bottom water SPM grain size during the flood. Percentage of the sedimentary fractions: sand fraction (Sand F; $>63 \mu \mathrm{m}$ ), silt fraction (Silt F; $2-63 \mu \mathrm{m}$ ), clay fraction (Clay F; $<2 \mu \mathrm{m}$ ) and fine fraction (Fine F, $<63 \mu \mathrm{m}$ ), in the stations of Ria de Aveiro Inlet (B1) and Mira Channel (MC), in the winter spring tide (WST), winter neap tide (WNT), summer spring tide (SST) and summer neap tide (SNT). b) Percentage of sedimentary grain size fractions in bottom water SPM, during winter spring tide in the stations of Ria de Aveiro Inlet (B4), S. Jacinto Channel (JC) and Mira Channel (MC), in flood and ebb tidal phases. c) SPM median grain size $(\mu \mathrm{m})$, in bottom water, during winter spring tide, in the station of Ria de Aveiro Inlet (B4), S. Jacinto Channel (JC) and Mira Channel (MC), during flood and ebb tidal phases. d) Bottom water SPM mineralogy during the flood, in summer and winter spring and neap tides, in the stations Aveiro Inlet (B1) and Mira Channel (MC). Percentage of phyllosilicates (Phy), quartz (Qz), K-feldspars (K-Fds), plagioclase (Plag) and calcite (Cal).

Fig. 10. - a) Tamaño de grano de las partículas en suspensión (SPM), del agua del fondo durante la bajamar. Porcentaje de las

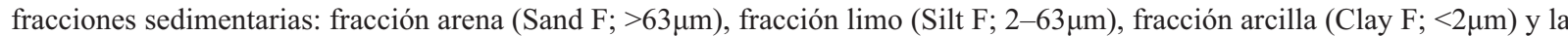
fracción fina (Fine F, $<63 \mu \mathrm{m}$ ), en las estaciones de la entrada de la Ría de Aveiro (B1) y del Canal de Mira (MC), en la marea viva en invierno (WST), en el marea muerta en invierno (WNT), en la marea viva en verano (SST) y en el marea muerta en verano (SNT). b) Porcentaje del tamaño de grano de fracciones sedimentarias en SPM, en el agua del fondo, en la marea viva en invierno, en la estación de la entrada de la Ría de Aveiro (B4), Canal de S. Jacinto (JC) y Canal de Mira (MC), en las fases de pleamar y bajamar. c) Tamaño mediano del grano de SPM, en agua del fondo, durante las mareas vivas en invierno, en las estaciones de la entrada de la Ría de Aveiro (B4), Canal de S. Jacinto (JC) y Canal de Mira (MC), en fases de flujo y de reflujo. d) Mineralogía de la SPM, en agua de fondo, durante la pleamar de las mareas vivas y mareas muertas en verano y en invierno, en las estaciones de entrada de la Ria de Aveiro (B1) y Canal de Mira (MC). Porcentaje de filosilicatos (Phy), cuarzo (Qz), K-feldespato (K-Fds), plagioclasa (Plag) y calcita $(\mathrm{Cal})$. 
SSC depends on climatic conditions, current velocities, river flooding and wind stress, while also being determined by the availability of sediments, whose sources include rivers, the ocean, and erosion areas as well as intertidal flats and salt marshes. However, there is a prevalence for higher SSC values during ebb and low tide throughout the year when compared to the flood. This may indicate a higher flux of sediments seaward than landward, provided from oceanic sources. The north and south jetty configuration and the sedimentary dynamic on the nearby continental shelf do not favour the sediments entrance into the lagoonal areas. Mostly muddy sediments leave the lagoon, composed essentially of quartz and phyllosilicates with a lower content of $\mathrm{K}$-feldspars, plagioclase and calcite.

This work also provides evidence that the study of the characteristics of bottom and suspended sediments can be useful in the recognition of erosional or depositional trends in coastal areas, in the discrimination of different sources of the sediments and in the characterization of patterns of the sedimentary flux.

\section{Acknowledgement}

The authors would like to thank the comments of the anonymous reviewers. The authors would like to thank the collaboration of Prof. Dr. V. Quintino, Dr. Cristina Freitas, Dr. Denise Terroso, Mr. João Graça, Mr. Rui Marques, for the technical support. This work was financed by the FCT (Portugal) through the EMERA (POCTI/ECM/59958/2004) and AdaptaRia (PTDC/ AAC-CLI/100953/2008) Projects, co-funded by COMPETE/QREN/UE.

\section{References}

Abecasis, C.K. (1955): The history of a tidal lagoon inlet and its improvement (the case of Aveiro, Portugal). Proceedings of the Fifth Conference on Coastal Engineering: 329-363.

Abrantes, I, Rocha, F. (2007): Sedimentary Dynamics of the Aveiro Shelf (Portugal). Journal of Coastal Research SI 50, 1005-1009.

Abrantes, I., Dias, J.M., Rocha, F. (2006). Spatial and temporal variability of suspended sediments concentration in Ria de Aveiro lagoon and fluxes between the lagoon and the ocean. Journal of Coastal Research SI39, 718-723.

Alejo, I., Austin, W.E.N., Francés, G., Vilas, F. (1999): Preliminary investigations of the recent foraminifera of Baiona Bay, NW. Spain. Journal of Coastal Research 15, 413-427.

Amaral, D.A. (1968): A laguna: vida, morte e ressurreição de Aveiro. Aveiro e o seu Distrito, Aveiro 6, 34-45.

Amorim, I. (2008): Recursos e infra-estruturas portuárias gestão e funcionalidade de um porto: Aveiro (1756-1857).
Revista da Faculdade de Letras: História, III Série, Porto, 9, 141-167.

Anthony, E.J., Héquette, A. (2007): The grain-size characterisation of coastal sand from the Somme estuary to Belgium: Sediment sorting processes and mixing in a tide - and stormdominated setting. Sedimentary Geology 202, 369-382. doi:10.1016/j.sedgeo.2007.03.022

Araújo I., Dias J.M., Pugh D. (2008): Model simulations of tidal changes in a coastal lagoon, the Ria de Aveiro (Portugal). Continental Shelf Research 28, 1010-1025. doi:10.1016/j. csr.2008.02.001

Cearreta, A. (1988a): Distribution and ecology of benthic foraminifera in the Santoña estuary, Spain. Revista Española de Micropaleontología 3, 23-38.

Cearreta, A. (1988b): Population dynamics of benthic foraminifera in the Santoña estuary, Spain. Revue de Paléobiologie 2, 721-724.

Cearreta, A. (1989): Foraminiferal assemblages in the Ria of San Vicente de la Barquera (Cantabria, Spain). Revista Española de Micropaleontología 12, 67-80.

Cearreta, A., Alday, M., Freitas, M.C., Andrade, C., Cruces, A. (2002): Modern foraminiferal record of alternating open and restricted environmental conditions in the Santo André lagoon, SW, Portugal. Hydrobiologia 475/476, 21-27. doi: 10.1023/A:1020384302366

Cearreta, A., Irabien, M.J., Leorri, E., Yusta, I., Croudace, I.W., Cundy, A.B. (2000): Recent anthropogenic impacts on the Bilbao estuary, northern Spain: geochemical and microfaunal evidence. Estuarine, Coastal and Shelf Science 50, 571592. doi:10.1006/ecss. 1999.0582

Dias, J.M.A., Ferreira, Ó., Pereira, A.R. (1994): Estudo Sintético de Diagnóstico da Geomorfologia e da Dinâmica Sedimentar dos Troços Costeiros entre Espinho e Nazaré. Esamin/Instituto de Conservação da Natureza, Lisboa: 261p.

Dias, J.M., Lopes, J.F. (2006): Implementation and assessment of hydrodynamic, salt and heat transport models: the case of Ria de Aveiro Lagoon. Portugal. Environmental Modelling and Software 21, 1-15. doi:10.1016/j.envsoft.2004.09.002

Dias, J.M., Lopes, J.F., Dekeyser, I. (2000): Tidal propagation in Ria de Aveiro Lagoon, Portugal. Physics and Chemistry of the Earth 25, 369-374. doi: 10.1016/S1464-1909(00)00028-9

Dias, J.M., Lopes, J.F., Dekeyser, I. (2001): Lagrangian transport of particles in Ria de Aveiro lagoon, Portugal. Physics and Chemistry of the Earth (B) 26, 721-727. doi:10.1016/ S1464-1909(01)00076-4

Dias, J.M.A., Jouanneau, J.M., Gonzalez, R., Araújo, M.F., Drago, T., Garcia, C., Oliveira, A., Rodrigues, A., Vitorino, J., Weber, O. (2002): Present day sedimentary processes on the northern Iberian shelf. Progress in Oceanography 52, 249-259. doi: 10.1016/S0079-6611(02)00009-5

Diz, P., Francés, G., Costas, S. Souto, C., Alejo, I. (2004): Distribution of benthic foraminifera in coarse sediments, Ria de Vigo, Nw Iberian Margin. Journal of Foraminiferal Research 34, 258-275. doi: 10.2113/34.4.258

Diz, P., Francés, Rosón, G. (2006): Effects of contrasting upwelling-downwelling on benthic foraminiferal distribution in the Ría de Vigo (NW Spain). Journal of Marine Systems 
60, 1-18. doi:10.1016/j.jmarsys.2005.11.001

Ellis, B.F., Messina, A.R. (1940 and subsequent): Catalogue of Foraminifera. The American Museum of Natural History, New York. Special Publication.

González-Regalado, M.L., Ruiz Muñoz, F., Flores, J.B. (1996): Evolución de la distribución de los foraminíferos bentónicos en un medio contaminado: el estuario del Río Odiel (Huelva, SO de España). Revista Española de Paleontología 11, 1-10.

Loeblich, A.R., Tappan, H. (1987): Foraminifera Genera and Their Classification. Van Nostrand Reinhold, New York.

Lopes, J.F., Dias, J.M., Dekeyser, I. (2006): Numerical modelling of cohesive sediments transport in the Ria de Aveiro lagoon, Portugal. Journal of Hydrology 319, 176-198. doi:10.1016/j.jhydrol.2005.07.019

Martins, V. Gomes, V. (2004): Foraminíferos da Margem Continental NW Ibérica: Sistemática, Ecologia. C. Gomes, (ed): $377 \mathrm{p}$.

Martins, V., Dubert, J., Jouanneau, J.-M., Weber, O., Silva, E.F., Patinha C., Alveirinho Dias, J.M., Rocha, F. (2007): A multiproxy approach of the Holocene evolution of shelf-slope circulation on the NW Iberian Continental Shelf. Marine Geology 239, 1-18. doi:10.1016/j.margeo.2006.11.001.

Moreira, H.M., Queiroga, H., Machado, M.M., Cunha, M.R. (1993): Environmental gradients in a southern estuarine system: Ria de Aveiro, Portugal, implication for soft bottom macrofauna colonisation. Netherlands Journal of Aquatic Ecology 27, 465-482.

Moreno, J., Fatela, F., Andrade, C., Cascalho, C., Moreno, F., Drago, T. (2005): Living foraminiferal assemblages from the Minho and Coura estuaries (northern Portugal): a stressful environment. Thalassas, 21, 17-28.

Muñoz, F.R., Montero, M.L., González, J.A. (1996): Distribución y ecología de los foraminíferos y ostrácodos actuales del estuario mesomareal del Río Guadiana (SO España). Geobios, 29, 513-528.

Murray, J.W. (1991): Ecology and palaeoecology of benthic foraminifera. London, Longman Scientific \& Technical: 397 p.

Oliveira, I.M., Valle, A.F., Miranda, F. (1982): Litoral Problems in the Portuguese West Coast. Coastal Engineering, 3, 1951-1969.

Pascual, A. (1984): Los foraminíferos actuales del litoral vizcaíno. Kobie, 14, 341-350.

Pascual, A. (1992): Utilización de los foraminiferos bentonicos para un mejor conocimiento del medio ambiente en los es- tuarios vizcaínos (Guernika y Bilbao). Revista Española de Micropaleontologia 24, 33-57.

Picado A., Dias J.M., Fortunato A., (2010): Tidal changes in estuarine systems induced by local geomorphologic modifications. Continental Shelf Research 30, 1854-1864. doi:10.1016/j.csr.2010.08.012

Plecha, S., Silva, P.A., Vaz, N., Bertin, X, Oliveira, A, Fortunato, A.B., Dias, J.M. (2010): Sensitivity analysis of a morphodynamic modelling system applied to a coastal lagoon inlet. Ocean Dynamics 60, 275-284. doi: 10.1007/s10236010-0267-5

Rocha, F., Galhano, A.C., Gomes C. (1999): Characterization and datation of Holocene mud layers from the urban area of Aveiro (Portugal). Cuaternario y Geomorfologia 13, 45-52

Shannon, C.E. (1948): A mathematical theory of communication. Bell System Technical Journal 27, 379-423.

Silva, P. A., Ramos M., Almeida, M., Dubert, J. (2006): Water exchange mechanisms between Ria de Aveiro and the Atlantic Ocean, Journal of Coastal Research, SI 39, 1622-1626.

Sousa, M., Dias, J.M. (2007): Hydrodynamic model calibration for a mesotidal lagoon: the case of Ria de Aveiro (Portugal). Journal of Coastal Research, SI50, 1075-1080.

Teixeira, S.L. (1994): Dinâmica morfossedimentar da Ria de Aveiro (Portugal). PhD. Thesis, Faculdade de Ciências da Universidade de Lisboa, Portugal: 397 p.

Vaz, N., Dias, J.M. (2008): Hydrographic characterization of an estuarine tidal channel. Journal of Marine Systems 70, 168-181. doi:10.1016/j.jmarsys.2007.05.002

Vaz, N., Dias, J.M., Leitão, P.C. (2009): Three-dimensional modelling of a tidal channel: the Espinheiro Channel (Portugal). Continental Shelf Research 29, 29-41. doi:10.1016/j. csr.2007.12.005

Vitorino, J., Oliveira, A., Jouanneau, J. M., Drago, T. (2002a): Winter dynamics on the northern Portuguese shelf. Part 1: physical processes. Progress in Oceanography 52, 129-153. doi: 10.1016/S0079-6611(02)00003-4

Vitorino, J., Oliveira, A., Jouanneau, J.M., Drago, T. (2002b): Winter dynamics on the northern Portuguese shelf. Part 2: bottom boundary layers and sediment dispersal. Progress in Oceanography 52, 155-170. doi:10.1016/S00796611(02)00004-6

Waeles, B., Le Hir, P., Lesueur, P., Delsinne N. (2007): Modelling sand/mud transport and morphodynamics in the Seine river mouth (France): an attempt using a processbased approach. Hydrobiologia 588, 69-82. http://dx.doi. org/10.1007/s10750-007-0653-2.

Appendix 1.- Sedimentological (grain size, geochemical and mineralogical data) and selected microfaunal results (Shannon index values, foraminifera density, percentage of the most abundant dead and living benthic foraminifera species and groups of species, including "Oceanic Specimens". Electronic file available as supplementary material in the online version of the paper.

Appendix 2.- Number and percentage of specimens per species in each station, of dead and living benthic foraminifera assemblages. Electronic file available as supplementary material in the online version of the paper. 